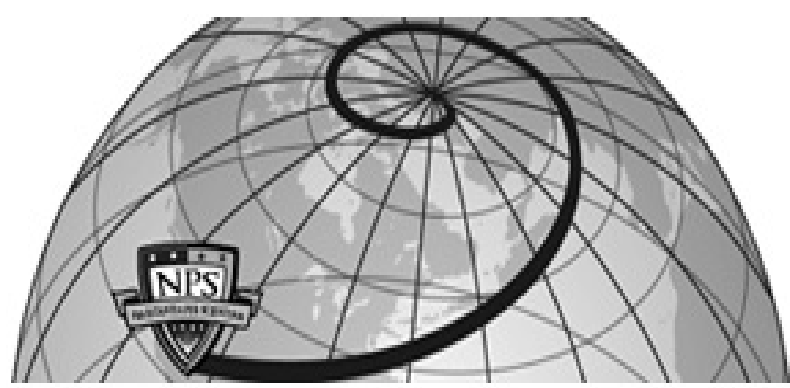

Calhoun: The NPS Institutional Archive DSpace Repository

\title{
An Analysis of academic assistance programs on at-risk students at the United States Naval Academy
}

Fallon, David M.

Monterey, California. Naval Postgraduate School

https://hdl.handle.net/10945/2156

This publication is a work of the U.S. Government as defined in Title 17, United States Code, Section 101. Copyright protection is not available for this work in the United States.

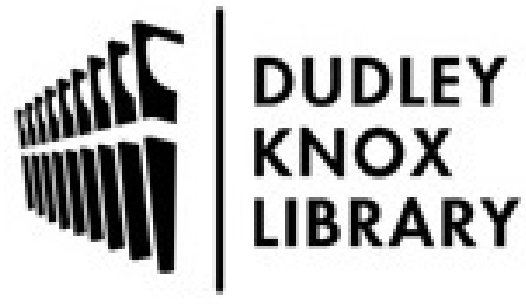

http://www.nps.edu/library
Calhoun is the Naval Postgraduate School's public access digital repository for research materials and institutional publications created by the NPS community. Calhoun is named for Professor of Mathematics Guy K. Calhoun, NPS's first appointed -- and published -- scholarly author.

Dudley Knox Library / Naval Postgraduate School 411 Dyer Road / 1 University Circle Monterey, California USA 93943 


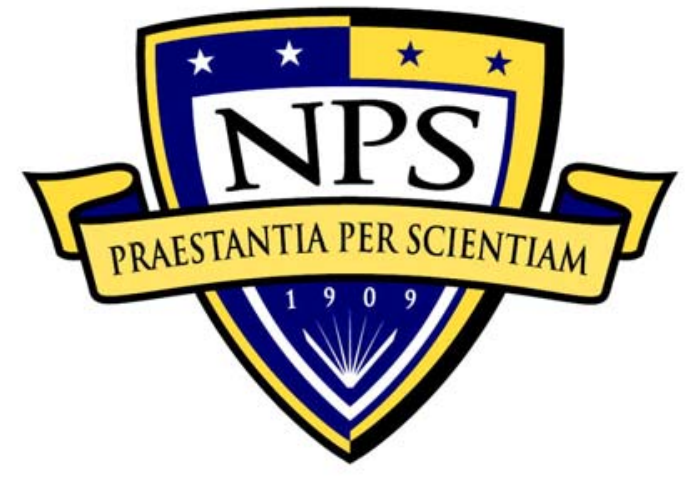

\section{NAVAL \\ POSTGRADUATE \\ SCHOOL}

MONTEREY, CALIFORNIA

\section{THESIS}

AN ANALYSIS OF ACADEMIC ASSISTANCE PROGRAMS ON AT-RISK STUDENTS AT THE UNITED STATES

NAVAL ACADEMY

by

David M. Fallon

June 2005

Thesis Co-Advisors:

Alice M. Crawford

William R. Bowman

Approved for public release; distribution is unlimited 
THIS PAGE INTENTIONALLY LEFT BLANK 
Public reporting burden for this collection of information is estimated to average 1 hour per response, including the time for reviewing instruction, searching existing data sources, gathering and maintaining the data needed, and completing and reviewing the collection of information. Send comments regarding this burden estimate or any other aspect of this collection of information, including suggestions for reducing this burden, to Washington headquarters Services, Directorate for Information Operations and Reports, 1215 Jefferson Davis Highway, Suite 1204, Arlington, VA 22202-4302, and to the Office of Management and Budget, Paperwork Reduction Project (0704-0188) Washington DC 20503.

\begin{tabular}{|c|c|c|c|}
\hline 1. AGENCY USE ONLY (Leave blank) & $\begin{array}{l}\text { 2. REPORT DATE } \\
\text { June } 2005\end{array}$ & \multicolumn{2}{|c|}{$\begin{array}{l}\text { 3. REPORT TYPE AND DATES COVERED } \\
\text { Master's Thesis }\end{array}$} \\
\hline \multicolumn{3}{|c|}{$\begin{array}{l}\text { 4. TITLE AND SUBTITLE: } \\
\text { An Analysis of Academic Assistance Programs on At-Risk Students at the } \\
\text { United States Naval Academy }\end{array}$} & 5. FUNDING NUMBERS \\
\hline \multicolumn{4}{|c|}{ 6. AUTHOR(S) } \\
\hline \multicolumn{3}{|c|}{$\begin{array}{l}\text { 7. PERFORMING ORGANIZATION NAME(S) AND ADDRESS(ES) } \\
\text { Naval Postgraduate School } \\
\text { Monterey, CA 93943-5000 }\end{array}$} & $\begin{array}{l}\text { 8. PERFORMING } \\
\text { ORGANIZATION REPORT } \\
\text { NUMBER }\end{array}$ \\
\hline \multicolumn{3}{|c|}{$\begin{array}{l}\text { 9. SPONSORING /MONITORING AGENCY NAME(S) AND ADDRESS(ES) } \\
\text { N/A }\end{array}$} & $\begin{array}{l}\text { 10. SPONSORING/MONITORING } \\
\text { AGENCY REPORT NUMBER }\end{array}$ \\
\hline
\end{tabular}

11. SUPPLEMENTARY NOTES The views expressed in this thesis are those of the author and do not reflect the official policy or position of the Department of Defense or the U.S. Government.

\begin{tabular}{l|l}
\hline 12a. DISTRIBUTION / AVAILABILITY STATEMENT & 12b. DISTRIBUTION CODE \\
Approved for public release; distribution is unlimited &
\end{tabular}

\section{ABSTRACT (maximum 200 words)}

The purpose of this research is to examine the impact of academic assistance programs on at-risk students at the United States Naval Academy. Each year, students determined to be at-risk are enrolled in an academic assistance program known as the Plebe Intervention Program. In addition, other academic assistance programs are available to these students. In particular, the Naval Academy administers a program known as the Midshipmen Group Study Program, which is based on the supplemental instruction model. This study examines the impact of participation in each of these programs as a determinant to persistence beyond the freshman year. Other determinants examined included demographics (ethnicity and gender), course grades, athletic status, and preadmittance data (SAT scores).

\begin{tabular}{|c|c|c|c|}
\hline \multicolumn{3}{|c|}{$\begin{array}{l}\text { 14. SUBJECT TERMS Academic Assistance Programs Supplemental Instruction At-Risk Students } \\
\text { Attrition United States Naval Academy }\end{array}$} & \multirow{2}{*}{$\begin{array}{l}\text { 15. NUMBER OF } \\
\text { PAGES } 95 \\
\text { 16. PRICE CODE }\end{array}$} \\
\hline & & & \\
\hline $\begin{array}{l}\text { 17. SECURITY } \\
\text { CLASSIFICATION OF } \\
\text { REPORT } \\
\quad \text { Unclassified }\end{array}$ & $\begin{array}{l}\text { 18. SECURITY } \\
\text { CLASSIFICATION OF THIS } \\
\text { PAGE } \quad \text { Unclassified }\end{array}$ & $\begin{array}{l}\text { 19. SECURITY } \\
\text { CLASSIFICATION OF } \\
\text { ABSTRACT } \\
\quad \text { Unclassified }\end{array}$ & $\begin{array}{l}\text { 20. LIMITATION } \\
\text { OF ABSTRACT } \\
\text { UL }\end{array}$ \\
\hline
\end{tabular}

NSN 7540-01-280-5500

Standard Form 298 (Rev. 2-89) Prescribed by ANSI Std. 239-18 
THIS PAGE INTENTIONALLY LEFT BLANK 
Approved for public release; distribution is unlimited

ATTRITION AT THE UNITED STATES NAVAL ACADEMY: AN ANALYSIS

OF ACADEMIC ASSISTANCE PROGRAMS ON AT-RISK STUDENTS

\author{
David M. Fallon \\ Major, United States Marine Corps \\ B.A., Boston College, 1994 \\ Submitted in partial fulfillment of the \\ requirements for the degree of \\ MASTER OF SCIENCE IN \\ LEADERSHIP AND HUMAN RESOURCE DEVELOPMENT \\ from the
}

\title{
NAVAL POSTGRADUATE SCHOOL
}

June 2005

$\begin{array}{ll}\text { Author: } & \text { David M. Fallon } \\ \text { Approved by: } & \begin{array}{l}\text { Alice M. Crawford } \\ \text { Thesis Co-Advisor }\end{array} \\ & \\ & \text { William R. Bowman } \\ & \text { Thesis Co-Advisor } \\ & \\ & \text { Douglas A. Brook, Ph.D. } \\ & \text { Dean } \\ & \text { Graduate School of Business and Public Policy }\end{array}$ 
THIS PAGE INTENTIONALLY LEFT BLANK 


\begin{abstract}
This research is designed to examine the impact of academic assistance programs at the United States Naval Academy on at-risk students. Each year, a percentage of students at the United States Naval Academy are enrolled in an academic assistance program known as the Plebe Intervention Program. This program is only offered to those students who are deemed at-risk and susceptible to academic difficulties. Another academic assistance program that is offered is known as the Midshipmen Group Study Program. This program, which is voluntary and offered to all students at the United States Naval Academy, is based on the supplemental instruction model that was developed at the University of Missouri-Kansas City.

This study analyzes the impact of each form of academic assistance in determining the likelihood of student progression beyond the freshman year. Students who represent the most at-risk students at the United States Naval Academy are compared against students with similar entrance characteristics. This study hypothesizes that student participation in each of the academic assistance programs correlates to persistence. In addition, this study hypothesizes that student participation in the Midshipmen Group Study Program leads to higher persistence rates among at-risk students than those who merely participate in the Plebe Intervention Program.

Results of the study indicate that participation in the Midshipmen Group Study Program leads to an increase in academic performance and higher persistence rates than those students who do not participate. In addition, students enrolled in the Plebe Intervention Program are no less likely to attrite during their freshman year than students with similar entrance characteristics that are not enrolled in the Plebe Intervention Program.
\end{abstract}


THIS PAGE INTENTIONALLY LEFT BLANK 


\section{TABLE OF CONTENTS}

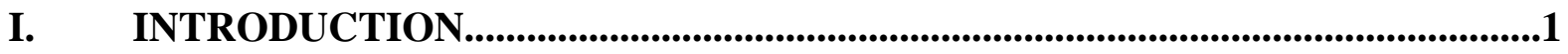

A. BACKGROUND ........................................................................................1

1. Plebe Intervention Program.......................................................................2

2. Midshipmen Group Study Program ...................................................2

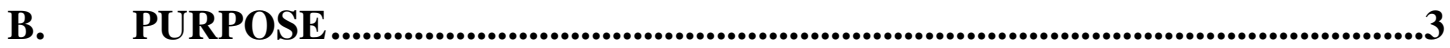

C. RESEARCH QUESTIONS .......................................................................................

D. BENEFITS OF THE STUDY ............................................................................

E. SCOPE AND METHODOLOGY .........................................................4

F. ORGANIZATION ..............................................................................................4

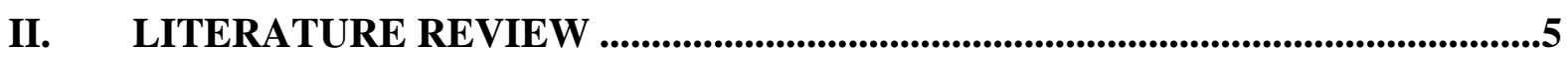

A. THE DEVELOPMENTAL LEARNER AND COLLEGE ATTRITION.....................................................................................................5

B. ATTRITION AND THE INSTITUTION'S DILEMMA ............................5

C. ATTRITION: THE IMPACT OF ACADEMIC PERFORMANCE ..........5

1. At-risk Students ....................................................................................6

2. Combating the Reluctant Learner ...........................................................6

D. ACADEMIC ASSISTANCE PROGRAMS: ALTERNATIVES...................7

1. Developmental Education .........................................................................

2. Remedial Courses...............................................................................8

3. Tutoring ..........................................................................................................9

4. Freshman Seminars ................................................................................9

5. Learning Communities and Collaborative Learning ...........................9

6. Learning to Learn Courses ................................................................10

E. SUPPLEMENTAL INSTRUCTION (SI) ....................................................10

1. Origins...................................................................................................10

2. Characteristics of SI ...........................................................................11

3. Frequency of SI Sessions ......................................................................12

4. Focus of an SI Session......................................................................12

5. Development of Learning and Thinking Skills ...................................13

6. Implementing SI...........................................................................................13

7. Role of the Professor ...................................................................................13

8. SI Leaders .....................................................................................14

F. RESULTS OF SI PROGRAMS..............................................................14

1. SI and Technical Courses.............................................................17

G. REASONS FOR SI SUCCESS ……..............................................................18

H. FINANCIAL IMPLICATIONS......................................................................19

I. METHODOLOGICAL DIFFICULTIES............................................19

1. Student Differences..........................................................................19

2. What to Analyze? .................................................................................20

3. Participation .......................................................................................20

4. Student Motivation ....................................................................................20

J. MEASURING MOTIVATION.......................................................21 
K. ACADEMIC ASSISTANCE PROGRAMS AT THE UNITED STATES NAVAL ACADEMY ...............................................................22

1. The Academic Center ................................................................22

2. Academic Center Programs ...................................................................22

a. Academic Counseling Program..................................................23

b. Learning Skills Program ..............................................................24

c. Plebe Programs ...............................................................................224

d. Plebe Advising Program .............................................................24

e. Plebe Intervention Program .................................................25

f. Tutoring Programs.....................................................................26

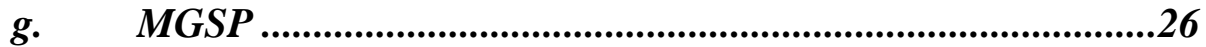

h. Hourly Tutoring ..........................................................................22

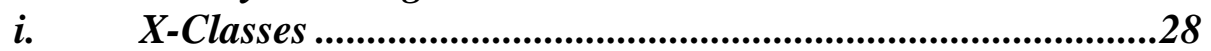

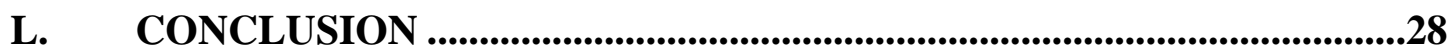

III. RESEARCH METHODOLOGY .......................................................................29

A. INTRODUCTION...............................................................................................29

B. DATA SOURCES ........................................................................................29

1. Office of Institutional Research, Planning and Assessment ...........29

2. Academic Center.....................................................................................30

3. Data Merge .....................................................................................................30

C. DEPENDANT VARIABLES ...........................................................................30

1. Plebe Intervention Program (PIP) and Watch-list Students ..........30

2. Attrition ............................................................................................31

3. Academic Performance .....................................................................32

D. INEPENDANT VARIABLES.............................................................................32

1. Plebe Intervention Program (PIP) .......................................................32

2. SAT Math average scores (SATMAVG).............................................33

3. SAT Verbal Average Scores (SAMVAVG) ..........................................34

4. Gender (GENDER2) ...............................................................................34

5. Ethnicity.....................................................................................................35

6. Whole Person Multiple (CM1000)........................................................36

7. Recommendations of the Admissions Board Scores (RAB500).....36

8. Recruited Athlete (BLUE).....................................................................37

9. Average Six-Week Grade (AVG6WK) ...................................................37

10. Participation in MGSP (MSGONE and MSGTWOMO).................38

11. Varsity Athlete during Freshman Year (VARPLEBE)....................39

E. RELATIONSHIP OF INDEPENDENT VARIABLES TO DEPENDANT VARIABLES ..............................................................39

1. PIP Model .....................................................................................................39

2. Attrition Model...........................................................................................41

a. Academic Attrition ................................................................42

b. Voluntary Attrition..................................................................43

3. Performance Differences .........................................................................43

F. QUALITATIVE DATA..................................................................................44

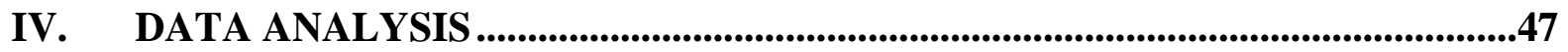

A. PIP PREDICTION MODEL (PIP AS DEPENDANT VARIABLE) .........47 
1. Discussion of Variables.................................................................48

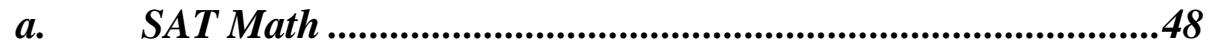

b. Recommendations of the Admissions Board...........................48

c. Whole Person Multiple ..................................................................49

d. Recruited Athletes ........................................................................49

B. ATTRITION MODEL (REASON FOR LEAVING AS DEPENDANT VARIABLE)

1. Discussion of Variables: Attrite Voluntarily ...................................51

a. Average Difference in Six-Week Grade and Final Grade.....51

b. Average Six-Week Grade ........................................................51

c. Participated in Two or More MGSP Sessions...........................51

d. Gender .....................................................................................52

e. Assigned to PIP ...................................................................52

2. Discussion of Variables: Attrite for Academic Reasons.................52

a. $\quad$ Average Differences in Six-Week Grade and Final Grade ...52

b. Average Six-Week Grade .............................................................52

c. Participation in Two or More MGSP Sessions .........................53

d. Ethnic Minorities ..............................................................53

e. Assigned to PIP .............................................................................53

C. PERFORMANCE MODEL (DIFFERENCE FROM SIXWEEKGRADE TO FINAL GRADE AS DEPENDANT VARIABLE)....54

1. Discussion of the Variables .............................................................55

a. Average Six-Week Grade ..............................................................55

b. SAT Math Score ............................................................................55

c. $\quad$ Participated in Two or More MGSP Sessions............................55

d. Ethnic Minorities ..................................................................56

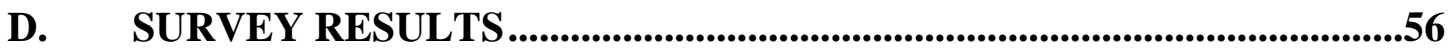

1. Academic Motivation..............................................................................56

2. Coping Skills.................................................................................................5

3. Social Motivation ......................................................................................57

4. Receptivity to Support Services................................................................58

5. Evaluation of Academic Assistance Programs.....................................58

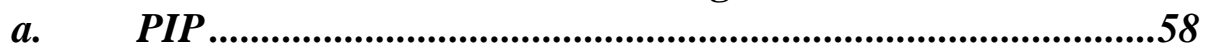

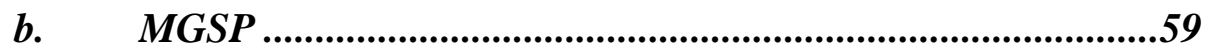

V. CONCLUSIONS AND RECOMMENDATIONS.....................................................61

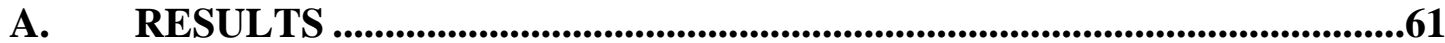

1. What are the differences between students selected for inclusion in the PIP as opposed to those assigned to the watchlist?

2. What is the impact of selected academic assistance programs on whether or not an at-risk student attrites at the Naval Academy during his or her freshman year?....

3. Do students solely enrolled in PIP experience greater academic improvement than other PIP students who also participate in MGSP? 
4. What is the impact of motivation on the performance of at-risk students? ............................................................................................62

B. RECOMMENDATIONS..................................................................62

1. Motivation Survey.................................................................................62

2. Continue PIP .............................................................................................62

3. Mandate MGSP for At-Risk Students ..................................................63

4. Improve MGSP Leaders...........................................................................63

C. RECOMMENDATIONS FOR FUTURE RESEARCH................................63

APPENDIX A: ACADEMIC SURVEY ............................................................................65

APPENDIX B: SPSS OUTPUT …….....................................................................................71

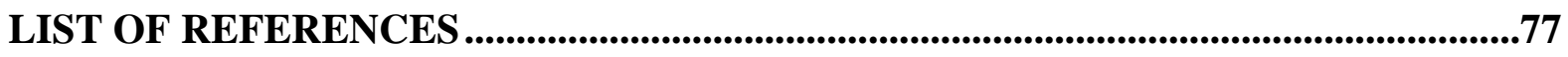

INITIAL DISTRIBUTION LIST ........................................................................................81 


\section{LIST OF TABLES}

Table 1.

SI UMKC Data: FY 1980-81 to 1998-99 …………………………….......16

Table 2.

National SI Field Data: FY 1982-1983 to 1995-1996 ………………….........17

Table 3.

National SI Field Data: FY 1982-83 to 1995-1996 .......................................18

Table 4.

Frequency of Selected Cases (AY2002-2005)...................................................31

Table 5.

Reason for Leaving (AY2002-2005) ...........................................................31

Table 6.

Difference in Six-Week Grade and Final Grade (AY2002-2005) ....................32

Table 7.

PIP Participants Academic Status at the End of Plebe Year (AY 2002-

2005)

Table $8 . \quad$ Differences in Scores Between PIP-Selected Students and Watch-List Selected Students on SAT Math (AY 2002-2005)

Table 9. Differences in Scores Between PIP-Selected Students and Watch-List Selected Students on SAT Verbal (AY 2002-2005) ........................................34

Table 10. Gender Composition of PIP and Watch-list (AY 2002-2005)...........................35

Table 11. Ethnicity Composition of PIP and Watch-list (AY 2002-2005) ........................35

Table 12. Chi-Square Values for Ethnicity Variables (AY2002-2005)..............................35

Table 13. Differences in WPM (x1000) of PIP and Watch-list Selected Students (AY 2002-2005) ............................................................................................

Table 14. Differences in Recommendations of the Admissions Board (x500) between PIP and Watch-list selected students (AY 2002-2005) ......................37

Table 15. Percentage of Recruited Athletes in PIP and Watch-list (AY 2002-2005).......37

Table 16. Mean Six-Week Grades of PIP and Watch-list Students (AY 2002-2005) .....38

Table 17. Participation in MGSP by PIP and Watch-list Students (AY 2002-2005) .......38

Table 18. Varsity Athletics Participation during Plebe Year (AY2002-2005) .................39

Table 19. Independent Variables Utilized to Predict Assignment to the PIP (AY 2002-2005)

Table 20. Predicted Effect of Independent Variables Utilized to Measure Attrition (AY2002-2005)......................................................................................42

Table 21. Independent Variables Utilized to Predict Effect on Differences Between Six-week Grades and Final Grade Awarded (AY2002-2005) ............................44

Table 22. Motivation Survey: Number of Questions per Category .................................45

Table 23. Logistic Regression Results (PIP as Dependant Variable) ...............................48

Table 24. $\quad$ Mean SAT Math Averages (AY2002-2005).....................................................48

Table 25. Attrite for Voluntary Reasons (Trinomial Regression Results).........................51

Table 26. Attrite for Academic Reasons (Trinomial Regression Results)........................52

Table 27. Performance Model (Difference in Six-Week Grade and Final Grade Awarded as Dependant Variable) .....................................................................55

Table 28. Selected Responses from Survey Data (Academic Motivation)........................57

Table 29. $\quad$ Selected Responses from Survey Data (Coping Skills).....................................57

Table 30. $\quad$ Selected Responses from Survey Data (Social Motivation) ...............................58

Table 31. Selected Responses from Survey Data (Receptivity to Support Services).......58

Table 32. Summary of PIP Evaluation.............................................................................59

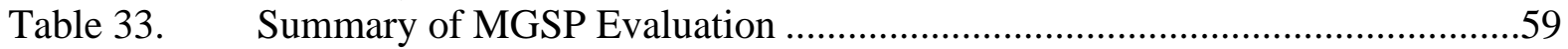


THIS PAGE INTENTIONALLY LEFT BLANK 


\section{INTRODUCTION}

\section{A. BACKGROUND}

Despite the fact that the United States Naval Academy is a military institution, it faces many of the same concerns of its private and public counterparts. Chiefly, however, the Naval Academy is responsible to the public and maintains the responsibility of preparing its graduates for service in our nation's armed forces. If the Naval Academy does not achieve its graduation goals, it stands the risk of weakening national security and wasting taxpayer money. Graduates from the Naval Academy are expected to assume leadership positions within the Navy and Marine Corps immediately upon their graduation.

Each year, admissions requirements at the Naval Academy are based upon the need for junior officers in the operating forces. Due to the nature of officer accessions, there does not exist the possibility of simply "hiring” another junior officer if a Naval Academy Midshipman is unable to complete his or her academic requirements. As a result, Midshipman retention and attrition are two issues that are very important to the Naval Academy.

Attrition at the Naval Academy is the result of a number of factors. Two reasons for which students attrite at the Naval Academy are academic deficiencies and voluntary disenrollment. Although there are other reasons for which a student might attrite (medical, conduct, professional, etc.), the focus of this study is on persistence at the Naval Academy.

Traditionally, students who are admitted to the Naval Academy have demonstrated exceptional academic achievement throughout their high school careers. Despite this, many are under prepared for the academic rigors at the Naval Academy. While all are admitted based on the belief that they will succeed academically, it is also assumed that all students will require some sort of academic assistance during their time at the Naval Academy (Academic Dean Instruction 1531.34A).

Like most colleges and universities throughout the country, the Naval Academy has also had to institute academic assistance programs in order to combat attrition and 
low academic achievement. In 1989, the Naval Academy formally addressed academic attrition by instituting a formalized academic assistance organization. This organization, known as the Academic Center, is responsible for the management and oversight of the various academic assistance programs employed at the Naval Academy. Programs offered at the Academic Center range from one-on-one instruction (tutoring) to studentled study sessions.

Two academic assistance programs that are administered by the Academic Center are the Plebe Intervention Program and the Midshipmen Study Group Program. Although each is a form of developmental education and whose aim is Midshipmen retention, each is very different from the other.

\section{Plebe Intervention Program}

As previously mentioned, every Midshipman is admitted to the Naval Academy under the premise that he or she will be able to complete the academic requirements. Despite this, the Naval Academy carefully analyzes the personal records of each admitted Midshipman in order to determine the likelihood of academic success. As a result of this process, a number of students are identified as possessing the individual characteristics that will make them most susceptible to academic difficulty. These students are enrolled in a program known as the Plebe Intervention Program (PIP). Once enrolled in PIP, students are assigned an academic advisor and enrolled in study skills classes. This program represents a proactive approach by the Naval Academy to identify those who are more likely to attrite and to provide early intervention for them.

\section{Midshipmen Group Study Program}

The second program that will be the focus of this study is the Midshipmen Group Study Program (MGSP). This program, which is based on the Supplemental Instruction model developed at the University of Missouri-Kansas City, provides student-led study sessions in courses that have traditionally been academically challenging to Midshipmen (Blanc, Debuhr, \& Martin, 1983). Unlike PIP, this program is completely voluntary.

There exists considerable debate within the developmental education community concerning the most effective form of academic assistance. While some argue that study skills based courses like PIP are appropriate for developing generic skills among students, others argue that content specific assistance programs (MGSP) are more 
successful. Although this study explores the differences between the two programs, the emphasis of the study focuses on an at-risk student's persistence beyond his or her freshman year.

Perhaps the most widely discussed explanation of a student's decision to participate in additional academic assistance is motivation. As a variable, motivation is difficult to analyze. In many studies, motivation has not been analyzed because the focus has been on quantitative data. This study attempts to measure an at-risk student's motivation to participate in a voluntary academic assistance program through a voluntary survey designed to measure motivation and determine the correlation with persistence.

\section{B. PURPOSE}

The overall objective of this thesis is to measure the impact of academic assistance programs on a student's persistence beyond his or her freshman year. The outcome variable to be analyzed will be attrition during a student's freshman year. By exploring the independent variables that correlate to persistence, the Naval Academy can better recruit potential applicants. In addition, this study will determine the most suitable academic assistance program for at-risk students. This will allow the Naval Academy to develop academic assistance programs to suit the needs of at-risk students.

\section{RESEARCH QUESTIONS}

- What are the differences between students selected for inclusion in the PIP as opposed to those assigned to the watch-list?

- What is the impact of selected academic assistance programs on whether or not an at-risk student attrites at the Naval Academy during his or her freshman year?

- $\quad$ Do students solely enrolled in PIP perform better in selected courses than other PIP students who also participate in MGSP?

- What is the impact of motivation on the performance of at-risk students?

\section{BENEFITS OF THE STUDY}

This study will allow the Naval Academy, and in particular the Academic Center to better develop academic assistance programs designed to meet the needs of at-risk 
students. In addition, this study will effectively evaluate the performance differences between students enrolled in PIP and MGSP.

\section{E. SCOPE AND METHODOLOGY}

The focus of this study is to determine the characteristics of at-risk students who led to their persistence or attrition at the Naval Academy. Data were collected on at-risk Midshipmen from year groups 2005-2008. This group was selected because they are still in attendance at the Naval Academy during this research and allowed for qualitative data collection.

A combination of quantitative and qualitative analysis was conducted as part of this research. Quantitative data were collected on participants that were determined to be at-risk from 2005-2008. Qualitative data analysis was conducted using a survey to measure motivation of PIP participants from 2005-2008.

\section{F. ORGANIZATION}

This thesis is divided into five chapters. Chapter II reviews the development of academic assistance programs designed to improve academic performance and curb attrition at post-secondary institutions across the United States. Chapter II also outlines the current academic assistance programs being utilized at the United States Naval Academy. Chapter III describes the methodology used in the collection and analysis of data for the study. Chapter IV presents the results of the quantitative and qualitative analysis. Chapter V provides conclusions and recommendations based on the analysis of the data. 


\section{LITERATURE REVIEW}

\section{A. THE DEVELOPMENTAL LEARNER AND COLLEGE ATTRITION}

As more Americans are admitted to institutions of higher learning, the need for academic assistance programs has increased dramatically. Despite the fact that students meet all admissions criteria, institutions have discovered that many college freshmen are academically under prepared when they arrive. As a result, many students fail to succeed academically and are not allowed to continue their education. In addition, some students experience such academic difficulty that they do not choose to reenroll. In both cases, the loss of revenue for the institution is dramatic. Tuition fees are the most obvious loss of revenue for the school when a student withdraws, but there are other associated costs that are also lost such as housing. As a result of these concerns, many schools have implemented academic assistance programs in order to better prepare a student for academic rigors and increase the chance of a students’ persistence to graduate.

\section{B. ATTRITION AND THE INSTITUTION'S DILEMMA}

The 1998 National Center for Education Statistics reported that 37 percent of beginning postsecondary students failed to complete any degree and were not enrolled in any academic program after five years (National Center for Education Statistics, 1998). College attrition has become the focus of many college administrators due to a number of reasons. In public and private institutions, attrition among their students results in loss of revenue and loss of prestige (Blanc, DeBuhr, Martin, 1983; Congos \& Schoeps, 1997).

\section{ATTRITION: THE IMPACT OF ACADEMIC PERFORMANCE}

In the past, studies have indicated that this high attrition rate directly corresponds to a student's poor academic performance, particularly in large entry-level courses (Daugherty \& Lane, 1999; Blanc, Debuhr, \& Martin, 1983). To improve retention rates and curb attrition, many schools have implemented programs designed to improve the academic success of their students (Patrik, J, Furlow, J.W., \& Donovan, S, 1988; Tinto, 1987; Noel et al., 1985). In the past, academic assistance programs were operated on a

drop-in basis. Students who were experiencing academic difficulty would seek out 
assistance. This is a reactive approach and depends on the students' self-awareness and willingness to seek assistance. Schools began to realize that some students who were experiencing academic difficulty were reluctant to seek assistance. Oftentimes, these students were those who failed to persist (Blanc, Debuhr, \& Martin, 1983). To combat this problem, many schools began developing academic assistance programs in the mid1980s that were of a proactive nature and sought to identify students before they experienced academic difficulty (Blanc, Debuhr, \& Martin, 1983).

School administrators are also faced with the dilemma that many students admitted are under prepared for the rigors of post-secondary education. Of all first-year students in college, nearly one-third require remedial education in reading, writing, or mathematics. This has led to the development of numerous academic assistance programs at colleges and universities throughout the country. These programs have been implemented for a number of reasons. One reason for this is that college students are not self-regulated learners (Simpson, Hynd, Nist, \& Burrell, 1997). Students have difficulty analyzing tasks, synthesizing information, monitoring their understanding of course material, and developing strategies for remembering what they have learned (Simpson, et al., 1997). It is for this reason that academic assistance programs have flourished throughout college campuses across the country (Simpson, et al., 1997). This need for remediation is growing and many students will require substantial remediation to meet graduation requirements (Bettinger \& Long, 2004).

\section{At-risk Students}

At-risk students pose other problems for administrators in the development of academic assistance programs. Research indicates that at-risk students are less inclined to self-select participation in academic assistance programs than non-at-risk students. In addition, at-risk students are also less inclined to continue to participate once enrolled (Blanc, Debuhr, \& Martin, 1980; Friedlander, 1980; Karabenick \& Knapp, 1988). Furthermore, the behavioral changes desired as a result of the assistance programs are not lasting (Dembo \& Seli, 2004).

\section{Combating the Reluctant Learner}

Many schools attempt to encourage participation in assistance programs. Despite the encouragement, studies show that in many cases no amount of encouragement will 
increase student participation (Hodges, 2001). Research indicates that there may be a number of reasons for these phenomena: first, at-risk students need stronger external influences to facilitate positive changes in their behavior. Second, at-risk students may have unrealistic perceptions about their academic abilities. In other words, they do not believe that they need assistance (Hodges, 2001).

\section{ACADEMIC ASSISTANCE PROGRAMS: ALTERNATIVES}

\section{Developmental Education}

Over the past two decades, there has been considerable emphasis on learning strategies of at-risk students. As institutions develop assistance programs to combat attrition and improve performance, increasingly more emphasis has been placed on the needs of the students as the point of departure in the development of such programs. This new emphasis on academic assistance has led to increased emphasis on developmental education. Developmental education is a field of practice and research within higher education with a theoretical foundation in developmental psychology and learning theory (National Association for Developmental Education $\{\mathrm{NADE}\}$, 2005). According to the National Association for Developmental Education, the definition of developmental education is:

Developmental education is a field of practice and research within higher education with a theoretical foundation in developmental psychology and learning theory. It promotes the cognitive and affective growth of all postsecondary learners, at all levels of the learning continuum. Developmental education is sensitive and responsive to individual differences and special needs among learners.

Developmental education programs and services commonly address academic preparedness, diagnostic assessment and placement, development of general and discipline-specific learning strategies, and affective barriers to learning.

Developmental education includes, but is not limited to:

-all forms of learning assistance, such as tutoring, mentoring, and supplemental instruction

-personal, academic, and career counseling 
-academic advisement

-coursework

This revolutionary approach to academic assistance indicates a new emphasis on instituting a variety of assistance programs based on the needs of the student. Traditionally, academic assistance was available only when a student voluntarily participated. Oftentimes, a student only participated after experiencing academic difficulty. In this approach, however, there exist additional methods for identification of students more prone to academic difficulty. More importantly, this approach realizes that not one approach is suitable for all students.

Despite the challenges that colleges and universities face in developing academic assistance programs, many schools have chosen to offer alternatives. Rather than offer a single academic assistance program, many schools offer various forms of academic assistance in an attempt to meet the needs of their students.

\section{Remedial Courses}

Developmental education typically includes such activities as remedial/developmental courses, tutoring, learning laboratories, and other forms of personalized instruction (National Association for Developmental Education, 2005). Of all the types of developmental education, the programs that spark the most debate are remedial programs (Boylan, 1999). There are a number of reasons that remedial programs are often criticized. First, the cost of administering such courses creates a fiscal burden on the schools that choose to implement them. Second, remedial courses take far too long and delay students from completing their degree because these are oftentimes non-credit courses. As a result, participation in such courses can extend a student's time at a school up to one year (Boylan, 1999).

Remedial courses are but one form of developmental education aimed at improving the performance of students. There are other forms of developmental education that can accomplish the same goals as remediation without the associated costs in term of money and/or time investment. 


\section{Tutoring}

Tutoring has long since been a staple as a developmental education program. Its success is undeniable. Studies indicate that tutoring has a positive impact on retention and graduation, course grades, course completion rates, and student attitudes toward instruction (Boylan, Bonham, Claxton, \& Bliss, 1992). It should be noted, however, that successful tutoring programs often include a very directive and comprehensive tutor training program (Boylan, Bliss, \& Bonham, 1997).

Tutoring is an academic assistance program that is generic. That is, it teaches strategies and techniques that are not particular to a single course (Simpson, et al., 1997).

\section{Freshman Seminars}

At most colleges and universities, students attend an orientation prior to the commencement of classes. These orientations typically last between two to three days and focus on the rules and regulations of the institution. Many educators, however, are rethinking the role of the freshman seminar. Rather than provide a comprehensive orientation at the beginning of the year, many educators espouse a freshman orientation program that takes place throughout the year (Boylan, 1999). Many schools even offer the freshman orientation as a full-credit course (Boylan, 1999). The purpose of such a program is to expose the students less to the rules and regulations, and more to the issues they face in college. Among these issues are retention, expectations, and purpose of higher education. While the freshman orientation does not lead to the development of learning skills, it is effective at introducing college issues and easing the adjustment of newly-arrived students (Fidler \& Goodwin, 1994).

\section{Learning Communities and Collaborative Learning}

Research has shown that college retention is positively related to a student's membership in various college academic clubs (Astin, 1993). As such, there exists an increased effort at many institutions to offer students the opportunity to be part of such communities. The premise of such a program is that the strongest community that most students will encounter while in college exists in the classroom (Boylan, 1999). Based on this, the emphasis of such a program is the development of relationships within the 
classroom that create a sense of group learning. In essence, students in such a learning community learn collectively, rather than in isolation (Boylan, 1999).

\section{Learning to Learn Courses}

In Learning to Learn Courses, students are taught learning strategies that can be employed in a variety of courses. Learning to learn courses emphasize a developmental approach rather than a deficient approach. Students are not singled out for their deficiencies. Rather, a developmental approach is introduced that is effective in a variety of courses. Cognitive aspects of learning and practical tips are introduced. In such courses, topics might include: learning from reading, learning from discussion, problem solving and creativity, writing, and/or test-taking strategies. In learning-to-learn courses, specific emphasis is placed upon a student's ability to self-monitor his or her performance. Although these types of courses are offered throughout the country, research indicates that teaching study skills without a particular content focus has little impact on a student’s academic performance (Martin \& Arendale, 1993).

\section{E. SUPPLEMENTAL INSTRUCTION (SI)}

\section{Origins}

Another academic assistance program that has been developed is known as SI. This program was created by Dr. Deanna Martin at the University of Missouri Kansas City in 1973. Currently, SI is one of only a few remediation programs designated by the United States Department of Education (USDOE) as an Exemplary Educational Program (Center for Supplemental Instruction, 1997). In addition, SI is the only program identified by USDOE as improving student academic performance and graduation (Center for Supplemental Instruction, 1997).

Supplemental Instruction, originally developed by the Student Learning Center (SLC) at the University of Missouri Kansas City (UKMC), represents a fundamentally different approach to combat high attrition rates (Center for Supplemental Instruction, 1997). Rather than focus on at-risk students, SLC focused on courses that traditionally produced some of the lowest grades by students. The SLC identified high-risk courses as those in which 30 percent of the students received a " $D$ " or " $F$," or withdrew from the course (Blanc, DeBuhr, \& Martin, 1983). Initially, SI was only offered in the health 
science professional schools, but was extended throughout the school after success was realized. Once a course was identified, the SLC designed an academic assistance program that focused on mastering course specific content, rather than an individual's special needs (Blanc, Debuhr, \& Martin, 1983).

SI is an academic assistance program that utilizes an embedded approach (Simpson et al., 1997). In this approach, specific strategies and techniques are introduced that apply only to a particular course. In such an approach, the emphasis is on the thinking process associated with mastery of a particular course. General study skills are not introduced. Although SI specifically targets a students' mastery of specific course content, it also develops reading, reasoning, and study skills (Blanc, DeBuhr, \& Martin, 1983).

\section{Characteristics of SI}

Supplemental Instruction focuses on high-risk courses, rather than on high-risk students (Blanc, Debuhr, \& Martin, 1983). In the design of such a program, this is an important aspect. Rather than single out a particular student or group, a course is identified as being the difficulty. This eliminates any stigma among the students who might be present if the emphasis were on the individual. Any student in the targeted course is eligible to participate in the program--not just those with academic difficulty. This has an enormous impact on participation. Whereas tutoring involves individual instruction, SI is characterized by group learning. As a result, students more often selected to participate in SI rather than tutoring (Hodges, 2001).

As high-risk courses are identified (introductory classes in which 30 percent or more of the students enrolled received grades of "D," "F," or "W"), students are hired who have taken the course and received an "A" grade. These students serve as leaders and are financially compensated for their participation. After receiving training in group dynamics and facilitation, the leaders attend all classes and complete the same assignments as those regularly enrolled in the course. The SI attendees are made aware of this in an attempt to strengthen the bond between the leader and the student (Congos \& Schoeps, 1993). To the students, the leader is viewed as "student of the subject" (Blanc, DeBuhr, \& Martin, 1983). That is, they serve as an example for the students to emulate based on their knowledge, curiosity in the subject, and professionalism. Although the 
leader is routinely viewed as an expert in the subject, the fact that he or she is also a student reduces the stigma associated with academic remediation. The leader works closely with the professor and provides valuable feedback. Oftentimes, the professor alters the course based on the feedback from the SI leader.

Central to a student's success in a particular course is his or her understanding of the academic tasks that will be encountered. It is only after a thorough understanding of the tasks that a student can develop the thinking processes required to produce the results desired by the instructor (Simpson et al., 1997). Because of the close linkage between the SI leader and the professor, this is easily accomplished. In essence, the student's understanding of the course equates to the professor's understanding of the course through the mediation of the SI leader.

\section{Frequency of SI Sessions}

SI sessions are typically held three times per week. Each session is approximately one hour in duration. Students typically attend one session per week. In terms of effectiveness of the program, most researchers indicate that students must attend at least five SI sessions during a given semester to maximize their success in the program (Martin et al. 1993).

\section{Focus of an SI Session}

The SI sessions are not merely a review of the course lectures. Rather, SI leaders discuss topics that are generated by the students. It is the role of the SI leader to identify course difficulties, provide strategies for dealing with the complexities, and determine the best manner in which the course content can be learned.

The atmosphere within the SI session is marked by group understanding and problem solving. Oftentimes, students collectively arrive at solutions to problems. As the SI leader poses questions to the group, the group is required to solve the problem by using various forms of thinking, reasoning, analyzing, and organizing. In other words,

the SI leader is attempting to develop cognitive skills within the students. As previously mentioned, it is these skills that many entry-level students lack and that often block the learning process at the undergraduate level (Congos \& Schoeps, 1993). 


\section{Development of Learning and Thinking Skills}

Central to leaders' responsibilities is the development of the students' learning and thinking skills. These skills, which are vital for content mastery, are largely underdeveloped in college freshmen (Blanc, DeBuhr, \& Martin, 1983). Rather than analyze and synthesize problems, college freshmen are more inclined and comfortable focusing on rote memorization and superficial details. It is for this reason that the leader is attentive to these needs.

In addition to developing these cognitive skills, the leader focuses on a student's mastery of the course content. As a regular participant in each of the classes, the leader is in-tune with the course progression. As a result, the leader can effectively lead discussions and review assignments. In addition, the leader is able to introduce alternative techniques to realize course mastery such as note-taking techniques, reading techniques, mnemonics, and test-taking strategies (Blanc, DeBuhr, \& Martin, 1983).

\section{Implementing SI}

As previously discussed, SI is voluntary program. Despite this, many institutions advertise SI in an attempt to increase participation (Blanc, DeBuhr, \& Martin, 1983; Congos \& Schoeps, 1993). SI leaders are presented as "masters" of the course. In addition, the leaders are purported to possess successful strategies specific to the course in which SI is being offered. Ultimately, however, students are informed that participation in the program will yield better grades.

\section{Role of the Professor}

For SI to be an effective academic assistance program for a particular course, the professor must be an active participant in the process. The professor must encourage student attendance at SI sessions to master the course content (Martin et al., 1993).

In addition, the professor must be willing to work closely with the SI leader. This requires full disclosure to the SI leader of course materials, exams, and lesson plans. Professors must also be willing to meet periodically with SI leaders to evaluate program effectiveness (Martin et al., 1993). 


\section{SI Leaders}

The success of an SI program is dependant on the quality of the individual leaders (Congos \& Schoeps, 1993). There are two primary methods for developing SI leaders that create an ideal learning environment: selection and training (Martin et al., 1993).

SI leaders must have demonstrated academic excellence throughout all aspects of the curriculum, not merely the course he/she is attempting to lead. SI leaders must possess a "B" average in all courses and earned an " $\mathrm{A}$ " in the specific course in which he/she will lead. In addition to this demonstrated academic excellence, particular attention must be given to an individual's interpersonal skills. Research indicates that students in an SI group who do not like their leader do not do as well as those in other groups who do like the leader (Congos \& Schoeps, 1993).

Although intelligence and interpersonal skills are requirements of SI leaders, there must still be an extensive training program for every SI leader. Typically, training for SI leaders consists of a series of seminars prior to the commencement of the class, and continues throughout the semester during weekly meetings with course coordinators/administrators. During these weekly meetings, specific problems and strategies are discussed for implementation in future SI sessions (Congos \& Schoeps, 1993).

\section{F. RESULTS OF SI PROGRAMS}

At UMKC and other institutions, SI has achieved tremendous success (Blanc, DeBuhr, \& Martin, 1983; Congos \& Schoeps, 1993, Congos \& Schoeps, 1993, Hodges, 2001). Studies have indicated that SI-students, when compared to non-SI students, maintain higher grade point averages (GPA) despite having lower entry-level data (Blanc, DeBuhr, \& Martin, 1983; Congos \& Schoeps, 1993). In multiple studies on the effectiveness of SI, researchers have shown that SI students in the highest and lowest quartiles of entry tests produced better academic performance than non-SI participants in the same quartiles (Blanc, DeBuhr, \& Martin, 1983; Congos \& Schoeps, 1993, Congos \& Schoeps, 1993). 
Table 1 is the result of an analysis on grades and withdrawal rates of students who participated in SI-targeted courses at UMKC from 1980-1999. The results of the analysis indicate that SI students earned a higher percentage of “A” and " $\mathrm{B}$ ” grades, lower percentage of “D” \& "F" grades and withdrawals, and higher mean final course grades than non-SI participants (Center for Supplemental Instruction, 2000). 
Table 1. SI UMKC Data: FY 1980-81 to 1998-99 (N=525 SI Courses; 19,962 SI-Participants; 31,368 Non-SI Participants)

\begin{tabular}{|c|c|c|c|c|c|c|}
\hline Year & $\begin{array}{c}\text { SI Participant } \\
\text { Status }\end{array}$ & $\begin{array}{c}\text { SI Participation Percent } \\
\text { and Number }\end{array}$ & $\begin{array}{l}\text { Number of } \\
\text { SI Courses }\end{array}$ & $\begin{array}{c}\text { Percent "A" } \\
\text { and “B” }\end{array}$ & $\begin{array}{c}\text { Percent “D,” } \\
\text { “F,” and } \\
\text { Withdrew }\end{array}$ & $\begin{array}{c}\text { Final } \\
\text { Course } \\
\text { Grade }\end{array}$ \\
\hline 1998-1999 & $\begin{array}{l}\text { SI } \\
\text { Non-SI }\end{array}$ & $\begin{array}{l}48.9(2,010) \\
51.1(2,044)\end{array}$ & 52 & $\begin{array}{l}54.4 \\
42.9\end{array}$ & $\begin{array}{l}20.2 \\
33.8\end{array}$ & $\begin{array}{l}2.70 \\
2.43\end{array}$ \\
\hline 1997-1998 & $\begin{array}{l}\text { SI } \\
\text { Non-SI }\end{array}$ & $\begin{array}{l}39.4(1,700) \\
60.6(2,606)\end{array}$ & 51 & $\begin{array}{l}55.1 \\
42.8\end{array}$ & $\begin{array}{l}19.0 \\
36.5\end{array}$ & $\begin{array}{l}2.65 \\
2.31\end{array}$ \\
\hline 1996-1997 & $\begin{array}{l}\text { SI } \\
\text { Non-SI }\end{array}$ & $\begin{array}{l}45.4(1,604) \\
54.6(1,929)\end{array}$ & 47 & $\begin{array}{l}55.9 \\
44.1\end{array}$ & $\begin{array}{l}16.7 \\
31.5\end{array}$ & $\begin{array}{l}2.66 \\
2.35\end{array}$ \\
\hline 1995-1996 & $\begin{array}{l}\text { SI } \\
\text { Non-SI }\end{array}$ & $\begin{array}{l}40.0(1,454) \\
60.0(2,181)\end{array}$ & 41 & $\begin{array}{l}52.0 \\
37.8\end{array}$ & $\begin{array}{l}21.6 \\
39.6\end{array}$ & $\begin{array}{l}2.64 \\
2.27\end{array}$ \\
\hline 1994-1995 & $\begin{array}{l}\text { SI } \\
\text { Non-SI }\end{array}$ & $\begin{array}{l}36.3(1,328) \\
63.7(2,330)\end{array}$ & 41 & $\begin{array}{l}52.6 \\
39.6\end{array}$ & $\begin{array}{l}20.8 \\
36.0\end{array}$ & $\begin{array}{l}2.84 \\
2.69\end{array}$ \\
\hline 1993-1994 & $\begin{array}{l}\text { SI } \\
\text { Non-SI }\end{array}$ & $\begin{array}{l}38.1(1,233) \\
61.9(2,003)\end{array}$ & 40 & $\begin{array}{l}49.0 \\
37.1\end{array}$ & $\begin{array}{l}23.1 \\
38.2\end{array}$ & $\begin{array}{l}2.52 \\
2.18\end{array}$ \\
\hline 1992-1993 & $\begin{array}{l}\text { SI } \\
\text { Non-SI }\end{array}$ & $\begin{array}{l}37.0(1,287) \\
63.0(2,191)\end{array}$ & 36 & $\begin{array}{l}55.6 \\
41.6\end{array}$ & $\begin{array}{l}20.7 \\
37.3\end{array}$ & $\begin{array}{l}2.84 \\
2.50\end{array}$ \\
\hline 1991-1992 & $\begin{array}{l}\text { SI } \\
\text { Non-SI }\end{array}$ & $\begin{array}{l}39.5(1,520) \\
60.5(2,328)\end{array}$ & 27 & $\begin{array}{l}56.4 \\
41.5\end{array}$ & $\begin{array}{l}19.2 \\
34.1\end{array}$ & $\begin{array}{l}2.69 \\
2.16\end{array}$ \\
\hline 1990-1991 & $\begin{array}{l}\text { SI } \\
\text { Non-SI }\end{array}$ & $\begin{array}{c}34.1(774) \\
65.9(1,496)\end{array}$ & 18 & $\begin{array}{l}53.4 \\
38.7\end{array}$ & $\begin{array}{l}16.0 \\
31.2\end{array}$ & $\begin{array}{l}2.61 \\
2.23\end{array}$ \\
\hline 1989-1990 & $\begin{array}{l}\text { SI } \\
\text { Non-SI }\end{array}$ & $\begin{array}{c}30.3(753) \\
69.7(1,732)\end{array}$ & 19 & $\begin{array}{l}58.3 \\
41.9\end{array}$ & $\begin{array}{l}16.7 \\
34.8\end{array}$ & $\begin{array}{l}2.70 \\
2.29\end{array}$ \\
\hline 1988-1989 & $\begin{array}{l}\text { SI } \\
\text { Non-SI }\end{array}$ & $\begin{array}{c}29.9(614) \\
70.1(1,439)\end{array}$ & 17 & $\begin{array}{l}63.2 \\
45.7\end{array}$ & $\begin{array}{l}15.6 \\
28.9\end{array}$ & $\begin{array}{l}2.81 \\
2.39\end{array}$ \\
\hline 1987-1988 & $\begin{array}{l}\text { SI } \\
\text { Non-SI }\end{array}$ & $\begin{array}{c}34.5(775) \\
65.9(1,498)\end{array}$ & 24 & $\begin{array}{l}60.4 \\
43.8\end{array}$ & $\begin{array}{l}13.7 \\
28.9\end{array}$ & $\begin{array}{l}2.80 \\
2.39\end{array}$ \\
\hline 1986-1987 & $\begin{array}{l}\text { SI } \\
\text { Non-SI }\end{array}$ & $\begin{array}{l}44.3(778) \\
55.7(978)\end{array}$ & 19 & $\begin{array}{l}56.3 \\
40.9\end{array}$ & $\begin{array}{l}18.3 \\
34.1\end{array}$ & $\begin{array}{l}2.65 \\
2.41\end{array}$ \\
\hline 1985-1986 & $\begin{array}{l}\text { SI } \\
\text { Non-SI }\end{array}$ & $\begin{array}{l}39.1(584) \\
60.9(910)\end{array}$ & 16 & $\begin{array}{l}51.5 \\
51.2\end{array}$ & $\begin{array}{l}18.7 \\
28.7\end{array}$ & $\begin{array}{l}2.55 \\
2.34\end{array}$ \\
\hline 1984-1985 & $\begin{array}{l}\text { SI } \\
\text { Non-SI }\end{array}$ & $\begin{array}{c}42.6(788) \\
57.4(1,062)\end{array}$ & 17 & $\begin{array}{l}59.7 \\
42.9\end{array}$ & $\begin{array}{l}16.8 \\
25.4\end{array}$ & $\begin{array}{l}2.83 \\
2.27\end{array}$ \\
\hline 1983-1984 & $\begin{array}{l}\text { SI } \\
\text { Non-SI }\end{array}$ & $\begin{array}{c}34.1(765) \\
65.9(1,478)\end{array}$ & 19 & $\begin{array}{l}54.5 \\
39.5\end{array}$ & $\begin{array}{l}17.3 \\
29.5\end{array}$ & $\begin{array}{l}2.76 \\
2.24\end{array}$ \\
\hline 1982-1983 & $\begin{array}{l}\text { SI } \\
\text { Non-SI }\end{array}$ & $\begin{array}{l}43.1(1,119) \\
56.9(1,477)\end{array}$ & 19 & $\begin{array}{l}52.2 \\
36.8\end{array}$ & $\begin{array}{l}17.9 \\
28.2\end{array}$ & $\begin{array}{l}2.51 \\
2.07\end{array}$ \\
\hline 1981-1982 & $\begin{array}{l}\text { SI } \\
\text { Non-SI }\end{array}$ & $\begin{array}{l}40.9(329) \\
59.1(475)\end{array}$ & 5 & $\begin{array}{l}58.2 \\
38.5\end{array}$ & $\begin{array}{l}20.9 \\
26.7\end{array}$ & $\begin{array}{l}2.61 \\
2.09\end{array}$ \\
\hline 1980-1981 & $\begin{array}{l}\text { SI } \\
\text { Non-SI }\end{array}$ & $\begin{array}{c}32.2(566) \\
67.8(1,192)\end{array}$ & 17 & $\begin{array}{l}50.1 \\
32.5\end{array}$ & $\begin{array}{l}14.2 \\
33.1\end{array}$ & $\begin{array}{l}2.56 \\
2.16\end{array}$ \\
\hline
\end{tabular}

From Center for Supplemental Instruction (2000) 
Success at UMKC cannot be debated. Studies conducted by the Center for Supplemental Instruction also indicate that the findings at UMKC are consistent with other schools across the country (Center for Supplemental Instruction, 2000). Table 2 examines national data from 270 institutions from across the country between 1982 and 1996.

Table 2. National SI Field Data: FY 1982-1983 to 1995-1996 $\mathrm{N}=270$ Institutions; 4,945 Courses; 505,738 students

\begin{tabular}{|l|l|c|c|c|c|c|}
\hline \multicolumn{1}{|c|}{$\begin{array}{l}\text { Student } \\
\text { Grades }\end{array}$} & & $\begin{array}{c}\text { All Institutions } \\
\text { N=4,945 }\end{array}$ & $\begin{array}{c}\text { Two-Year } \\
\text { Public } \\
\text { N=931 }\end{array}$ & $\begin{array}{c}\text { Two-Year } \\
\text { Private } \\
\mathbf{N = 2 0}\end{array}$ & $\begin{array}{c}\text { Four-Year } \\
\text { Public } \\
\mathbf{N = 3 , 0 0 1}\end{array}$ & $\begin{array}{c}\text { Four-Year } \\
\text { Private } \\
\text { N=994 }\end{array}$ \\
\hline Final Course & SI & 2.42 & 2.56 & 2.55 & 2.36 & 2.55 \\
Grade & Non-SI & 2.09 & 2.09 & 2.26 & 2.07 & 2.31 \\
\hline Percent A \& B & SI & 46.8 & 53.1 & 53.1 & 53.1 & 53.1 \\
Final Grade & Non-SI & 35.9 & 32.4 & 38.9 & 38.9 & 43.2 \\
\hline Percent D, F, & SI & 23.1 & 24.3 & 24.6 & 24.6 & 19.1 \\
and W Final & Non-SI & 37.1 & 32.4 & 31.5 & 31.5 & 28.4 \\
Grade & & & & & & \\
\hline
\end{tabular}

From Center for Supplemental Instruction (2000)

Table 2 reflects findings from academic institutions from across the United States that are similar to those discovered at UMKC. SI participants earned a higher final course grade, had a higher percentage of “ $A$ ” and “ $B$ ” grades, and received less “D,” " $F$," and "W" final grades than non-SI participants. These findings are consistent for both the majority as well as minority students (Blanc, DeBuhr, \& Martin, 1983).

Despite the documented success of SI, early intervention remains crucial to improving student performance. If students delay participation in the program until later in the semester, they rarely achieve the same level of success as those who participate from the very beginning of the semester. If a student experiences academic difficulty as early as the six-week point in a semester, the chances are low that any academic assistance will be effective (Martin et al. 1993).

\section{SI and Technical Courses}

Success of SI-participating students applies to both liberal arts courses and more technically oriented courses. To institutions such as the Naval Academy, which offer a highly technical curriculum, this is a particularly compelling reason to pursue such a 
program. Analysis of over 270 institutions from across the country show that SIparticipating students performed better than non-SI-participating students in courses such as calculus, chemistry, engineering, and physics as shown in Table 3.

Table 3. National SI Field Data: FY 1982-83 to 1995-1996 N=270 Institutions; 4, 4945 Courses; 505,738 Students

Data Separated by Academic Departments

\begin{tabular}{|l|l|c|c|c|}
\hline \multicolumn{1}{|c|}{ Types of Courses } & & $\begin{array}{l}\text { Percent “A” and “B” } \\
\text { (chi-square test) }\end{array}$ & $\begin{array}{l}\text { Percent “D," “F”" and } \\
\text { "W" (chi-square test) }\end{array}$ & $\begin{array}{l}\text { Final Course Grade } \\
\text { (independent t-test) }\end{array}$ \\
\hline All Courses & SI & 46.8 & 23.1 & 2.42 \\
N=4,945 & Non-SI & 35.9 & 37.1 & 2.10 \\
& p-value & 0.01 & 0.01 & 0.01 \\
\hline Calculus & SI & 43.1 & 32.4 & 2.26 \\
N=143 & Non-SI & 37.2 & 42.5 & 2.06 \\
& p-value & 0.05 & 0.05 & 0.01 \\
\hline Chemistry & SI & 46.2 & 23.2 & 2.40 \\
N=718 & Non-SI & 36.9 & 36.5 & 2.08 \\
& p-value & 0.05 & 0.05 & 0.01 \\
\hline Engineering & SI & 37.8 & 33.3 & 2.16 \\
N=63 & Non-SI & 30.0 & 44.2 & 1.91 \\
& p-value & 0.05 & 0.05 & 0.01 \\
\hline Physics & SI & 45.1 & 24.4 & 2.42 \\
N=129 & Non-SI & 35.9 & 36.9 & 2.02 \\
& p-value & 0.05 & 0.05 & 0.02 \\
\hline
\end{tabular}

From Center for Supplemental Instruction (2000)

\section{G. REASONS FOR SI SUCCESS}

Since its inception, SI has been considered a highly effective academic assistance program. Studies have proven that SI effectiveness is undeniable (Blanc, DeBuhr, \& Martin, 1983, Congos \& Schoeps, 1993, Congos \& Schoeps, 1993, Hodges, 2001). There are a number of reasons for which this has occurred. First and foremost, students who attend SI do not have the stigma that they are deficient. Rather, the course is targeted. Second, SI is effective at improving the academic performance of students from various subpopulations. Regardless of academic preparation, gender, age, ethnicity, academic discipline, or whether or not a student works has not been found to significantly impact the effectiveness of SI (Martin \& Arendale, 1993, Center for Supplemental Instruction, 1997). 
SI is geared toward content-specific skills, rather than generic learning strategies. While learning strategies are taught, they are geared toward the specific course in which SI is offered. As a result, students are developing knowledge in specific area while simultaneously developing effective learning strategies.

\section{H. FINANCIAL IMPLICATIONS}

The cost for colleges and universities to offer academic remediation programs is high. At public institutions alone, an estimated $\$ 1$ billion is spent on remedial programs (Maxwell, 1992). This cost has led many to question whether or not remedial programs should be offered. Some states (e.g., Connecticut and Arizona) do not allow remediation at their public institutions (Maxwell, 1992). Other states have chosen to restrict remediation to only its two-year institutions. In addition, some states have placed the financial burden on the student's former high school. In some states (e.g., Minnesota and Virginia), high schools are held accountable for their student's preparedness (Maxwell, 1992). In these cases, the costs associated with a student's remedial programs are billed directly to the high school (Maxwell, 1992).

Despite the costs associated with academic remedial programs, the fact is that there are under prepared students who are enrolled in our colleges and universities. Many schools now faced with the burden of financing such academic remediation programs are seeking more cost-effective programs to address their student's needs (Maxwell, 1992).

At the same time, SI remains the most cost effective remedial program available to institutions because the leaders do not receive monetary compensation. Rather than hire tutors, SI allows schools to "pay" tutors (leaders) in academic credits. The cost effectiveness of such programs far outweighs the traditional approach (Maxwell, 1992).

\section{METHODOLOGICAL DIFFICULTIES \\ 1. Student Differences}

Although many studies indicate that SI is a successful alternative to traditional academic assistance, there are difficulties associated with evaluating the effectiveness of the program. Many researchers have postulated that attendees of SI sessions represent a 
different type of student: dedicated, motivated, and ambitious (Congos \& Schoeps, 1993). Therefore, it is difficult to compare non-SI students to SI students because it is assumed that the SI students possess many positive characteristics that are not common in non-SI students. In other words, the success of the program may not be due to the program, but simply due to the fact that the students who self-select have superior abilities (Congos \& Schoeps, 1993). This self-selection bias is addressed throughout the research and many researchers have attempted to deal with it through qualitative methods of evaluation.

\section{What to Analyze?}

Another problem in evaluating the effectiveness of such academic assistance programs is identifying the outcome variable to be analyzed. While many researchers analyze such variables as test scores, final course grades, and GPAs, others have argued that more qualitative measurements must be used due to the subtle factors that affect a student's academic experience, such as work status, socialization, and athletic status (Congos \& Schoeps, 1993). In such cases, a student's experiences may vary based on time demands and ability to concentrate solely on academic requirements.

\section{Participation}

Finally, many studies differ on their definition of an SI participant. In some studies, a student is viewed as an SI participant if he or she attended one session. It is arguable, however, that a student who only attends a single session is benefiting from the program (McCarthy \& Smuts, 1997).

\section{Student Motivation}

Student motivation has been identified as a critical predictor of a student's academic success, yet it is difficult to measure (Simpson, et al., 1997). The significance of motivation cannot be understated. Students who possess motivation are more likely to employ self-regulating strategies that improve their academic performance (Simpson, et al., 1997). Studies also indicate that students who do not possess motivation are less likely to persist in their coursework (Simpson, et al., 1997). In addition, they lack the fortitude to adequately respond to academic setbacks and are more inclined to accept academic difficulty and mediocrity (Simpson, et al., 1997). 


\section{J. MEASURING MOTIVATION}

As discussed, student motivation is another confounding variable in research examining the effectiveness of SI because it is difficult to measure. For example, some studies at UKMC have attempted to analyze motivation, but failed to differentiate between motivation to excel in coursework and motivation to participate in academic assistance programs. Many researchers indicate a need for better methods to analyze the effects of motivation in studies examining the effectiveness of SI (e.g., Congos \& Schoeps, 1993; McCarthy \& Smuts, 1997).

Although students who are assigned to developmental education programs are considered less academically capable than their peers, they also may possess individual characteristics that prevent them from achieving academic excellence. As more and more research on developmental education is being conducted, there is increasingly more evidence that certain students possess less academic motivation and, as a result, are less likely to achieve academic excellence (Morrison, 1999).

At many institutions, student motivation is measured using the College Student Inventory (CSI). Currently, over 500 institutions across the country utilize the CSI as an early intervention tool to assist at-risk students. The CSI is used to identify which students in the freshman population are most in jeopardy of academic difficulty and attrition. Based on the results of the self-reported survey, institutions can provide early intervention and devise personalized academic assistance programs.

The CSI is comprised of 194 items contained in 17 different scales. The survey is organized in five main categories: academic motivation, social motivation, general coping skills, receptivity to support services, and initial impression of the institution (Noel \& Levitz, 1985).

Although many schools utilize the CSI to measure motivation and identify at-risk students, many other schools utilize the Learning and Study Strategies Inventory (LASSI). The LASSI is an inventory of a students' self-awareness about the use of learning and study strategies related to skill, will, and self-regulation components of strategic learning (LASSI website, 2005). The outcome of a student's responses to the 
80-item inventory can lead to early intervention and a personalized academic assistance program.

\section{K. ACADEMIC ASSISTANCE PROGRAMS AT THE UNITED STATES NAVAL ACADEMY}

\section{The Academic Center}

To provide academic support to the Brigade of Midshipmen, the United States Naval Academy established the Academic Center in 1989. The mission of the Academic Center is to "support the mission of the Naval Academy by providing the highest quality academic support programs for the entire Brigade of Midshipmen.” (Academic Center, 2003). The goals of the Academic Center are:

- $\quad$ Provide excellent academic support services for all Midshipmen so that they are able to work to their highest potential in a rigorous educational environment.

- $\quad$ Teach basic learning skills necessary for effective academic performance.

- $\quad$ Encourage active, independent learning.

The initial impetus to establish such an organization was a report generated by the Minority Midshipmen Study Group that indicated the need for a proactive academic support program for academically challenged Midshipmen. In its infancy, the Academic Center focused primarily on the identification and remediation of academically substandard Midshipmen. Over the years, however, the scope of the Academic Center's focus has broadened. Currently, the Academic Center offers a host of academic support programs to meet the needs of the entire Brigade of Midshipmen.

Located in Ward Hall at the Naval Academy, the Academic Center is staffed by full-time employees, hourly employees, faculty members, and Midshipmen. The director of the Academic Center supervises four program directors, one full-time reading and learning instructor, one full-time tutor, six departmental liaisons, and approximately 85 Midshipmen study group leaders.

\section{Academic Center Programs}

To meet its goals, the Academic Center administers four programs: Academic Counseling Programs, Learning Skills Programs, Plebe Programs, and Tutoring Programs. Although each program will be discussed, the focus of this study will be the 
Plebe Programs and the Tutoring Programs. Information on each of these programs was obtained through various sources. The following is a list of sources from which this research is based:

- Academic Dean Instruction 1531.56J. (2004) United States Naval Academy. Plebe Advising Handbook.

- $\quad$ Annual Report of the Academic Center (2002-2003), United States Naval Academy

- $\quad$ Midshipmen Groups Study Program (n.d.) Retrieved Jan 13, 2005 from World Wide Web: http://usna.edu/MGSP/become_a_leader.htm

- $\quad$ United States Naval Academy Academic Center (2005, Feb 12) Retrieved Feb 12, 2005 from the World Wide Web: http://www.usna.edu/AcCenter/

- $\quad$ United States Naval Academy Academic Dean and Provost Instruction 1531.34A: Academic Support Programs. 25 Aug 92

- Interview, Director of Plebe Programs, Academic Center, 8 Dec 04

- Interview, Director, Midshipmen Group Study Program, Academic Center, 10 Dec 04

\section{a. Academic Counseling Program}

The Academic Counseling Program is designed to improve the academic performance of upper-class Midshipmen. Following a Midshipmen’s Plebe academic year, he/she may be assigned to participate in the Academic Counseling Program based on past academic performance. There are two programs within the Academic Counseling Program to which a Midshipman may be assigned. Category I is designed for Midshipmen who do not have a quality point ratio (QPR) above a 2.0 or are two courses behind in their matrix. Midshipmen assigned to this program are assigned an academic advisor from the Academic Center and are mandated to meet periodically with the advisor. Each year, approximately 60 Midshipmen are selected to participate in this program. Category II is designed for Midshipmen who have a history of academic difficulty, but have a QPR above a 2.0. These Midshipmen are assigned an academic advisor from the major department with whom they can meet. The performance of Category II Midshipmen is monitored by the Academic Center. Approximately 50 Midshipmen are selected to participate in this program annually. 


\section{b. Learning Skills Program}

The Learning Skills Program consists of three programs designed to improve academic performance of all Midshipmen by developing and/or refining learning skills. Each semester, approximately 200 Midshipmen self-select to participate in this

program. All programs offered through the Learning Skills Program are available to all Midshipmen, not merely those experiencing academic difficulty. The three programs offered through the Learning Skills Program are: Learning Skills Course, Individual Learning Skills Sessions, and Training Workshops. All of these courses focus on improving a Midshipman's learning skills through the introduction and application of such topics as time management strategies, note taking skills, test taking strategies, and stress management. The most significant difference between the various programs is the ratio of instructor to student. For example, in the Individual Learning Skills Sessions, a Midshipman is provided with one-on-one instruction. In all other programs, however, there are multiple students participating in the courses.

\section{c. Plebe Programs}

There are two primary programs offered to incoming Midshipmen at the Naval Academy: the Plebe Intervention Program and the Plebe Advising Program. These programs are designed to assist incoming Midshipmen to adjust to the academic rigors of the Naval Academy. Although the Plebe Advising Program offers services to all incoming Midshipmen, the Plebe Intervention Program is designed to assist those incoming Midshipmen who have been determined to have a greater potential for academic difficulty.

\section{d. Plebe Advising Program}

The Plebe Advising Program is offered to all incoming Midshipmen. This program offers basic instruction in learning skills strategies in an informal setting. Each year, two academic advisors are assigned to each company within the Brigade of Midshipmen who are available for academic assistance and guidance. These advisors typically assist the Plebes in matters such as course registration, major selection, and general academic assistance. Although the frequency in which a Plebe will meet with his/her advisor may vary, it is the goal of the institution for advisors to meet with each Plebe at least three times each semester. 


\section{e. Plebe Intervention Program}

While the Plebe Advising Program is offered to all incoming Midshipmen, the Plebe Intervention Program (PIP) is only offered to those incoming Midshipmen who have been identified as possessing characteristics that make them susceptible to academic difficulties at the Naval Academy. Plebes assigned to this program are provided with periodic academic counseling by advisors from the Academic Center. In addition, participants are provided instruction in learning skills strategies. At the end of the academic year, participants in the Plebe Intervention Program are enrolled in the Academic Counseling Program in either the Category I program or the Category II program.

Selection for participation in the Plebe Intervention Program is the result of cooperative analysis between the Academic Center and the Admissions Office. Each summer, prior to the arrival of the incoming class of Midshipmen, the Admissions Office identifies incoming Midshipmen who may or may not be potential candidates for participation in the Plebe Intervention Program. This list is forwarded to the Academic Center for further analysis. The Academic Center analyzes the individual records of each of the incoming Midshipmen and generates a "watch-list." This watch-list typically consists of 200 incoming Midshipmen. The primary variables that are analyzed to determine placement on the watch-list are Scholastic Aptitude Test (SAT) and Whole Person Multiple (WPM). The SAT criteria for placement on the watch-list are scores below 500 on the verbal portion and scores below 600 on the math portion. Incoming Midshipmen with WPM less than 60,000 are typically assigned to the watch-list. Although the initial watch-list is based largely on objective variables, recommendations are also received from the Admissions Board and the Naval Academy Athletic Association (NAAA) for individuals who may need additional academic support and should be included in the Plebe Intervention Program.

During Plebe Summer, upon arrival at the Naval Academy, the students are subjected to validation and placement exams for the institution's core courses. These tests measure three main abilities and serve as the indicator for assignment to the various levels of courses during academic year: mathematical, English, and science (chemistry and physics). Students who score poorly on these exams may be added to the watch-list. 
Following the examinations during Plebe Summer, the list is finalized and further analyzed to determine the final composition of the PIP. Only those who are deemed most susceptible to academic difficulty are selected for inclusion in the program. Of the approximately 200 individuals who comprise the watch-list, 60 or so are selected to participate in the Plebe Intervention Program.

Inclusion in the PIP is based solely on quantitative data analysis. Currently, there is no qualitative analysis being conducted on in-coming Midshipmen to determine academic motivation. In the past, the Academic Center utilized the LASSI to identify Midshipmen who might be more inclined to experience academic difficulty. In 2001, however, the Naval Academy discontinued administering this inventory.

\section{f. Tutoring Programs}

The Academic Center offers three different tutorial programs to the Brigade of Midshipmen: the Midshipmen Study Group Program (MGSP), Hourly Tutoring, and X-Class Tutoring. Participation in any of these programs is not mandatory and all tutorial services are available for the entire Brigade.

\section{g. MGSP}

The purpose of the MGSP is to "help all students in historically difficult classes master the course content, while at the same time helping them to develop personal learning techniques and study strategies.” (Academic Center, 2003). Modeled after the Supplemental Instruction Program developed at the University of Missouri Kansas City in 1973, the MGSP has experienced significant growth in the past five years. Initiated in 1997, MGSP was only offered in the general chemistry courses. Over the course of the next seven years, however, the program has expanded to provide academic support in pre-calculus courses, calculus courses (Calculus I and II), statics course, dynamics course, and physics courses.

MGSP study sessions typically consist of practicing homework problems and test preparation. In addition, however, many MGSP sessions involve reviewing concepts covered during lectures, discussing laboratory results and findings, as well as discussions of assigned readings (Midshipmen Group Study Program, n.d.). 
Similarly to the program initiated at the University of Missouri Kansas City, the primary instructors in the MGSP are students who have demonstrated academic excellence in the area in which they provide academic support. Candidates for study group leaders are solicited by the Academic Center and are carefully selected by the program's coordinator. Each year, approximately 70 Midshipmen are involved in the program. While some may serve as study group leaders, others may serve as discipline leaders and are responsible for coordinating program requirements and supervising Study Group Leaders. Criteria for selection as a Study Group Leader are as follows:

- $\quad$ Cannot be a Plebe. Only First-class through Third Class Midshipmen are eligible.

- $\quad$ Good academic standing within the Brigade.

- Validated the course during Plebe Summer examinations or received an "A" or "B" in the course in which they will be the study group leader.

- $\quad$ Receive a recommendation from a faculty member within the department of the course in which they will be a Study Group Leader.

Upon selection as a Study Group Leader, a Midshipman participates in a training and education program designed to provide the Study Group Leader with basic pedagogical skills. This training continues throughout the academic year and consists of periodic workshops that address such topics as methodology, theory, and practice of leading small group study sessions. In addition, Study Group Leaders are required to meet with faculty representatives to determine appropriate and suitable instruction topics for each of the study group sessions.

The MGSP leaders do not receive financial compensation for their participation in the course. Rather, they earn academic credits. Those Midshipmen who serve as group session leaders receive one credit. Midshipmen who serve as supervisors receive two credits.

\section{h. Hourly Tutoring}

Hourly tutoring is provided by the Academic Center for those Midshipmen who are experiencing severe academic difficulty. In addition, they have utilized other Academic Center services and have not responded to the assistance. 
At the Academic Center, there are eight part-time tutors and one full-time tutor. Tutors are available for specific assistance in calculus, chemistry, physics, engineering, and Spanish.

For Midshipmen to be eligible for hourly tutoring, they must complete an on-line application. Upon completion of the survey, the Academic Center schedules an appointment with the Midshipman and conducts an historical analysis of his/her academic performance. Not every student who applies for hourly tutoring is approved (Academic Center, 2003). Again, it is only those who are in the most need that are approved for the program.

\section{i. $\quad X$-Classes}

This program works in conjunction with the PIP. The purpose of the program is to provide early intervention for students who have been identified as likely to experience academic difficulty.

Currently, X-Classes are only offered in calculus. These courses, which are not credit earning, are paired with the Midshipman's regular course of study. In addition, very few Midshipmen are permitted attendance. For example, during the Fall semester FY04, only six Midshipmen were enrolled in the X-Classes (Academic Center, 2004). During an X-Class, Midshipmen review and practice problems under the supervision of a professional tutor.

\section{CONCLUSION}

Although it is not their primary mission, the Academic Center provides academic assistance to at-risk students to reduce attrition. This is done through a variety of programs that are grounded in theoretical research. Although each program has been successful, there has yet to be a single study examining whether or not one approach is more successful than the others. 


\section{RESEARCH METHODOLOGY}

\section{A. INTRODUCTION}

The purpose of this study is to analyze the impact of academic assistance programs at the United States Naval Academy on at-risk student retention during his or her freshman year. Because a student is most vulnerable to attriting during his or her freshman year, only the freshman year is analyzed. Essentially, this study measures whether or not a student's participation in academic assistance programs will lead to higher retention rates during a student's freshman year. In addition to this fundamental research question, the following questions will be answered:

- What are the qualitative differences between students selected to the PIP as opposed to those selected for the watch-list?

- $\quad$ Is there a quantifiable difference in performance between students selected for participation in PIP as opposed to those selected for the watch-list?

The Naval Academy's Office of Institutional Research, Planning and Assessment and the Academic Center provided performance and demographic data used in this study. Information from these sources was merged to provide performance and demographic information on the individuals included in the study. In addition, a survey measuring academic motivation was administered to selected Midshipmen currently attending the Naval Academy. The study examines the performance differences among remedial students admitted to the Naval Academy from the classes of 2005 through 2007.

\section{B. DATA SOURCES}

\section{Office of Institutional Research, Planning and Assessment}

The Naval Academy's Office of Institutional Research, Planning and Assessment provided the demographic and performance information for each officer included in this study. Established in 1992, this office is responsible for evaluating institutional data and assisting in the development of admissions and educational processes at the Naval Academy. IR is also responsible for administering all surveys to Midshipmen, faculty, 
and staff at the Naval Academy (USNA IR Homepage, 2005). To accomplish its mission and goals, IR maintains a data warehouse that contains information on every Midshipman. Inputs into the data warehouse begin during the admissions process and throughout his or her matriculation.

As part of this study, IR provided information on those students who participated in the PIP as well as those students identified as part of the watch-list from the classes of 2005 through 2007. The dataset consisted of 909 cases. Of the 909 cases, 166 were participants in the PIP. Of the 166 selected, 130 persisted until at least their sophomore year. The remaining cases analyzed (743) were those selected to be on the watch-list.

\section{Academic Center}

Another source of information relevant to this study is maintained by the Academic Center. The Academic Center provides oversight of all academic assistance programs at the Naval Academy. The Academic Center provided information on the students selected for inclusion in the PIP and the watch-list from AY 2002-2005. This data set consisted of 166 participants in PIP and 743 selectees for the watch-list. The total number of cases was 909 .

\section{Data Merge}

Data from IR and the Academic Center were merged utilizing a Midshipman's alpha code. The dataset consists of those Midshipmen who were assigned to the PIP as well as the watch-list. The dataset consists of 909 cases.

\section{DEPENDANT VARIABLES}

\section{Plebe Intervention Program (PIP) and Watch-list Students}

At the United States Naval Academy, students determined to be most at-risk are assigned to the PIP. Thus, students selected for this program are determined to be most susceptible to attrition during their freshman year. Another group that is determined to be at-risk is those placed on the watch-list. Though not as susceptible as those in the PIP, these students have been identified by the Naval Academy to possess certain qualities that may require additional assistance if they fail to successfully meet the academic requirements of their course of study. These students are monitored throughout their freshman year and may be enrolled in additional academic assistance programs if the 
need arises. To analyze differences between the two groups, a logistic regression was utilized using PIP as the dependant variable. The model incorporated selected independent variables that will be discussed later in the chapter. Table 4 outlines the frequencies of each of the groups.

Table 4. Frequency of Selected Cases (AY2002-2005)

\begin{tabular}{|l|c|c|c|}
\hline & PIP (Percent) & Watch-list (Percent) & Total (Percent) \\
\hline $\mathrm{N}$ & $166(18.3 \%)$ & $743(81.7 \%)$ & $909(100 \%)$ \\
\hline
\end{tabular}

\section{Attrition}

As discussed in the literature review, students are most susceptible to attrite during their freshman year. There are a number of reasons for which a student may attrite. At the Naval Academy, there are four main categories used to classify reasons why a student attrites: academic, voluntarily, involuntarily (conduct/honor related), and/or medical. For the purposes of this study, only academic and voluntary attrites are analyzed. Academic attrites are analyzed because they failed to meet the academic requirements of the institution. Voluntary attrites are analyzed because they choose not to persist. As discussed in the literature review, oftentimes students disenroll despite significant academic difficulties. Some examples for which a student might disenroll would be lack of motivation or personal reasons.

To analyze attrition at the Naval Academy during a student's freshman year, a binomial regression model is utilized with 'reason for leaving' as the dependant variable. There were three categories analyzed: retention, attrition due to academic difficulties, and attrition due to voluntary reasons. Table 5 represents the reasons for which students attrited during their freshman year at the Naval Academy.

Table 5. Reason for Leaving (AY2002-2005)

\begin{tabular}{|l|c|c|}
\hline & Frequency & Percent \\
\hline Voluntary & 93 & $10.2 \%$ \\
\hline Involuntary & 10 & $11.3 \%$ \\
\hline Academic & 63 & $18.2 \%$ \\
\hline Medical & 9 & $19.2 \%$ \\
\hline Remain & 734 & $100 \%$ \\
\hline Total & 909 & \\
\hline
\end{tabular}




\section{Academic Performance}

Per the literature review, academic performance is closely correlated to persistence. When students perform well in the classroom, it is more likely that they will persist in their education. Conversely, students who do poorly in the classroom are more inclined to fail to persist. At the United States Naval Academy, the Administration has implemented a number of academic assistance programs to improve performance and, thus, encourage persistence. Two programs that are discussed in the literature review are the PIP and the MGSP. Each of these programs is designed to improve the academic performance of the participants. The third model to be analyzed measures the academic performance of students with similar characteristics (PIP and Watch-list) based on their participation or non-participation in academic assistance programs. To measure the effectiveness of the assistance, the dependant variable to be analyzed is the change in grade from the six-week mark in a particular course and the final grade that was awarded to the student (AVGDIF). Only core courses are analyzed. These core courses, which are required by all freshmen at the Naval Academy, include: Calculus I, Calculus II, Chemistry I, and Chemistry II. Of the 909 cases in the study, grades in these courses are available for 586 students. An Ordinary Least Squares (OLS) model is used to analyze the dependant variable. Specific independent variables to be included in the model will be discussed later in the chapter. Table 6 describes the dependant variable (difference in six-week grade and final grade).

Table 6. Difference in Six-Week Grade and Final Grade (AY2002-2005)

\begin{tabular}{|l|c|c|c|c|c|}
\hline & N & Minimum & Maximum & Mean & $\begin{array}{c}\text { Standard } \\
\text { Deviation }\end{array}$ \\
\hline $\begin{array}{l}\text { Average } \\
\text { Difference }\end{array}$ & 586 & -2 & 2 & -0.07 & 0.48 \\
\hline Total & 586 & & & & \\
\hline
\end{tabular}

\section{INEPENDANT VARIABLES}

\section{Plebe Intervention Program (PIP)}

As discussed in the literature review, students admitted to the Naval Academy determined to be the most at-risk are enrolled in the PIP. Based on their entrance data, these students are more likely to attrite than those not enrolled in the program. It is for 
this reason that they are afforded additional assistance. This variable (PIP) is related to two dependant variables: attrition and performance. During AY 2002-2005, 166 students were enrolled in the PIP. Of the 166, 36 (or 22\%) did not persist to their sophomore year of studies. Thus, 130 (or 78\%) students completed their freshman year. Table 7 provides data on those students enrolled in the PIP during AY 2002-2005 and their status at the end of their freshman year.

Table 7. PIP Participants Academic Status at the End of Plebe Year (AY 20022005)

\begin{tabular}{|l|l|c|c|}
\hline & & Frequency & Percent \\
\hline Reason For Leaving & & & \\
\hline & Voluntary & 15 & $9.04 \%$ \\
\hline & Academic & 19 & $11.45 \%$ \\
\hline $\begin{array}{l}\text { Persisted to Sophomore } \\
\text { Year }\end{array}$ & Medical & 2 & $1.2 \%$ \\
\hline & & 130 & $78.31 \%$ \\
\hline & Total & 166 & 100 \\
\hline
\end{tabular}

\section{SAT Math average scores (SATMAVG)}

At the United States Naval Academy, there is a heavy emphasis on technical courses. These courses often have a foundation in mathematics. Scores on the math portion of the SAT are believed to be closely correlated to a student's performance in many courses offered at the Naval Academy. For the purpose of this study, the courses being analyzed are Chemistry and Calculus. Thus, a students' performance on the math portion of the SAT will be included. Table 8 details the differences in scores between PIP selected students, watch-list selected students, and total population. PIP students, on average, scored 32 points lower on the math portion of the SAT than watch-list students. In addition, an independent samples means test was conducted and the t-value was -7.84 . 
Table 8. Differences in Scores Between PIP-Selected Students and Watch-List Selected Students on SAT Math (AY 2002-2005)

\begin{tabular}{|l|c|c|c|}
\hline & $\begin{array}{c}\text { PIP } \\
\text { Selected } \\
\text { Students }\end{array}$ & $\begin{array}{c}\text { Watch-List } \\
\text { Selected Students }\end{array}$ & Total Population \\
\hline Valid N & 166 & 743 & 909 \\
\hline $\begin{array}{l}\text { SAT } \\
\text { Math } \\
\text { Average }\end{array}$ & & & 570 \\
\hline Minimum & 544 & 576 & \\
\hline Maximum & 620 & 425 & 420 \\
\hline $\begin{array}{l}\text { Standard } \\
\text { Deviation }\end{array}$ & 450 & 760 & 760 \\
\hline
\end{tabular}

\section{SAT Verbal Average Scores (SAMVAVG)}

As part of the admissions process, SAT Verbal scores are closely scrutinized. Performance on the verbal portion of the SAT is closely related to each of the dependant variables. Table 9 details the average scores on the verbal portion of the SAT for the PIP-selected students, watch-list selected students, and the total population. On average, PIP students scored 13 points lower on the verbal portion of the SAT than watch-list students. An independent samples means test was conducted and the t-value was -2.46.

Table 9. Differences in Scores Between PIP-Selected Students and Watch-List Selected Students on SAT Verbal (AY 2002-2005)

\begin{tabular}{|l|c|c|c|}
\hline & $\begin{array}{c}\text { PIP } \\
\text { Selected } \\
\text { Students }\end{array}$ & $\begin{array}{c}\text { Watch-List } \\
\text { Selected Students }\end{array}$ & Total Population \\
\hline $\mathrm{N}$ & 166 & 743 & 909 \\
\hline SAT Verbal Average & 542 & 555 & 553 \\
\hline Minimum & 364 & 330 & 330 \\
\hline Maximum & 686 & 790 & 790 \\
\hline Standard Deviation & 61.53 & 55.35 & 65.4 \\
\hline
\end{tabular}

\section{Gender (GENDER2)}

Gender is an independent variable that is related to all dependant variables selected. Table 10 details the gender composition of the PIP, the watch-list, and the total population. Gender representation is consistent in each group as there is only a $2.5 \%$ 
difference in female representation in each of the groups. An independent samples means test was conducted and produced a t-value of 3.15.

Table 10. Gender Composition of PIP and Watch-list (AY 2002-2005)

\begin{tabular}{|l|c|c|c|}
\hline & PIP (Percent) & $\begin{array}{c}\text { Watch-list } \\
\text { (Percent) }\end{array}$ & $\begin{array}{c}\text { Total Population } \\
\text { (Percent) }\end{array}$ \\
\hline Male & $135(81.3 \%)$ & $623(83.8 \%)$ & $758(83.4 \%)$ \\
\hline Female & $31(18.7 \%)$ & $120(16.2 \%)$ & $151(16.6 \%)$ \\
\hline Total & 166 & 743 & 909 \\
\hline
\end{tabular}

\section{Ethnicity}

Ethnicity is an independent variable related to all dependant variables. Ethnicity is divided into four subpopulations: Caucasian (CAUCASIAN), African American (AFRICANAMERICAN), Hispanic (HISPANIC), and Other Ethnicities (OTHERETHNIC). Table 11 details the ethnic composition of the PIP, the watch-list, and the total population. Table 12 outlines the chi-square value for each variable. Although Caucasian representation in the PIP is consistent with watch-list assignment, African American representation on the PIP exceeds the watch-list (+5.2\%). In addition, Hispanics are more represented in PIP than the watch-list (+4.1\%).

Table 11. Ethnicity Composition of PIP and Watch-list (AY 2002-2005)

\begin{tabular}{|l|c|c|c|}
\hline & PIP (Percent) & $\begin{array}{c}\text { Watch-list } \\
\text { (Percent) }\end{array}$ & $\begin{array}{c}\text { Total Population } \\
\text { (Percent) }\end{array}$ \\
\hline Caucasian & $109(65.7 \%)$ & $481(64.7 \%)$ & $590(64.9 \%)$ \\
\hline African American & $33(19.9 \%)$ & $109(14.7 \%)$ & $142(15.5 \%)$ \\
\hline Hispanic & $19(11.4 \%)$ & $115(15.5 \%)$ & $134(14.7 \%)$ \\
\hline Other Ethnicities & $5(3 \%)$ & $38(5.1 \%)$ & $43(4.7 \%)$ \\
\hline Total & 166 & 743 & 909 \\
\hline
\end{tabular}

Table 12. Chi-Square Values for Ethnicity Variables (AY2002-2005)

\begin{tabular}{|l|c|c|c|}
\hline Ethnicity & Chi-Square Value & df & Significance \\
\hline Caucasian & .051 & 1 & .821 \\
\hline African American & 2.79 & 1 & .095 \\
\hline Hispanic & 1.76 & 1 & .185 \\
\hline Other Ethnicities & 1.33 & 1 & .249 \\
\hline
\end{tabular}




\section{Whole Person Multiple (CM1000)}

Applicants to the Naval Academy are awarded an objective score based on calculations of specific admissions criteria such as highest SAT or converted ACT scores in math and verbal, official rank in class, participation in extracurricular activities, and recommendations of school officials. This is done to evenly evaluate candidates' qualifications. Because a students' whole person multiple (WPM) is based on past high school performance, it can be used as a predictor of future performance. Table 13 contains the average WPM of students selected for the PIP and the Watch-list. (Note: scores depicted in the table represent a student's WPM divided by one thousand.) In addition, an independent samples means test was conducted and produced a t-value of 5.46 .

Table 13. Differences in WPM (x1000) of PIP and Watch-list Selected Students (AY 2002-2005)

\begin{tabular}{|l|c|c|c|}
\hline & PIP & Watch-list & $\begin{array}{c}\text { Total } \\
\text { Population }\end{array}$ \\
\hline Mean WPM & 57.38 & 59.54 & 59.15 \\
\hline Minimum & 47.23 & 46.2 & 46.21 \\
\hline Maximum & 67.4 & 73.07 & 73.07 \\
\hline $\begin{array}{l}\text { Standard } \\
\text { Deviation }\end{array}$ & 3.92 & 4.76 & 4.69 \\
\hline $\mathrm{N}$ & 166 & 743 & 909 \\
\hline
\end{tabular}

\section{Recommendations of the Admissions Board Scores (RAB500)}

The Admissions Board at the Naval Academy is authorized by the Superintendent to award Recommendations of the Admissions Board to individual candidates if the candidate's candidate multiple does not accurately reflect his potential and motivation to succeed in a career in the Naval Service. As evidenced in his or her complete application (such as high achievement in extra curricular activities participation or other factors that are not measurable) the Admissions Board may award a candidate additional points toward his or her candidate multiple. These points, known as RABs, are awarded in 500 point increments. This variable is important to include because it indicates that a student possesses intangible qualities that give the Board reason to believe he or she will succeed at the Naval Academy. Table 14 details the average RABs awarded to PIP selected students, watch-list selected students, and the total population. On average, PIP students 
receive more RABs than watch-list students. This may be due to the fact that PIP students, because of their high school records, are more in need of such assistance.

Table 14. Differences in Recommendations of the Admissions Board (x500) between PIP and Watch-list selected students (AY 2002-2005)

\begin{tabular}{|l|c|c|c|}
\hline & PIP & $\begin{array}{c}\text { Watch- } \\
\text { list }\end{array}$ & $\begin{array}{c}\text { Total } \\
\text { Population }\end{array}$ \\
\hline $\begin{array}{l}\text { RABs } \\
\text { Awarded }\end{array}$ & 7.51 & 5.8 & 6.1 \\
\hline Minimum & -1 & -2 & -2 \\
\hline Maximum & 26 & 27.6 & 27.6 \\
\hline $\begin{array}{l}\text { Standard } \\
\text { Deviation }\end{array}$ & 5.56 & 5.15 & 6.11 \\
\hline Total & 166 & 743 & 909 \\
\hline
\end{tabular}

\section{Recruited Athlete (BLUE)}

At the Naval Academy, certain recruited athletes are granted waivers to allow them to be admitted. These "blue chip" athletes are allowed to attend the school despite having candidate multiple scores below 60,000. Table 15 contains data on the composition of recruited athletes (blue chip) in PIP, the Watch-list, and the total population. PIP students are much more likely to be recruited athletes than watch-list students (54\% to $30 \%)$. An independent samples means test was conducted and produced a t-value of 5.82 .

Table 15. Percentage of Recruited Athletes in PIP and Watch-list (AY 2002-

2005)

\begin{tabular}{|l|c|c|c|}
\hline & PIP (Percent) & $\begin{array}{c}\text { Total } \\
\text { Watch-list } \\
\text { (Percent) }\end{array}$ & $\begin{array}{c}\text { Population } \\
\text { (Percent) }\end{array}$ \\
\hline $\begin{array}{l}\text { Recruited Athlete (Blue } \\
\text { Chip) }\end{array}$ & $89(53.61 \%)$ & $225(30.28 \%)$ & $314(34.54 \%)$ \\
\hline
\end{tabular}

\section{Average Six-Week Grade (AVG6WK)}

In selected courses, scores were retrieved at the six-week period. These courses were Chemistry I, Chemistry II, Calculus I, and Calculus II. These courses were analyzed because all freshman must complete these courses during their freshman year. Grades in these courses were only available for 586 cases. Of the 166 cases in the PIP, grades were known for 112 students. Of the 743 cases in the Watch-list, grades were 
known for 474 . Table 16 outlines the differences in six-week grades between PIP, the watch-list selected students, and the total population. On average, PIP students were outperformed by watch-list students (-.72). An independent samples means test produced a t-value of -9.29 .

Table 16. Mean Six-Week Grades of PIP and Watch-list Students (AY 20022005)

\begin{tabular}{|l|c|c|c|}
\hline & PIP & Watch-list & $\begin{array}{l}\text { Total } \\
\text { Population }\end{array}$ \\
\hline Mean & 1.53 & 2.25 & 2.11 \\
\hline Minimum & 0 & 0 & 0 \\
\hline Maximum & 3.33 & 4 & 4 \\
\hline Standard Deviation & 0.73 & 0.73 & 0.78 \\
\hline N & 112 & 474 & 586 \\
\hline
\end{tabular}

\section{Participation in MGSP (MSGONE and MSGTWOMO)}

As noted in the literature review, MGSP is a form of SI designed to prevent attrition. In addition, it was also noted in the literature review that degree of participation is often debated. As a result, two independent variables were created to address this conflict. The first independent variable (MSGONE) created was to determine if a student participated in zero or one MGSP session. It was determined that participation in one MGSP session during an entire year may not constitute active participation. The second variable created (MSGTWOMO) determined if a student participated in two or more MGSP sessions during his or her freshman year. Because SI is aimed at improving retention, these variables are relevant to the study. Table 17 contains data on the differences between PIP, the watch-list, and the total participation. In addition, Table 17 contains the t-value as a result of an independent samples means test. In all cases, PIP students participated in MGSP more than watch-list students.

Table 17. Participation in MGSP by PIP and Watch-list Students (AY 20022005)

\begin{tabular}{|l|c|c|c|c|}
\hline \multicolumn{1}{|c|}{ Frequency } & PIP (Percent) & $\begin{array}{c}\text { Watch-list } \\
\text { (Percent) }\end{array}$ & $\begin{array}{c}\text { Total Population } \\
\text { (Percent) }\end{array}$ & T-value \\
\hline Never Attended & $95(57.2 \%)$ & $493(66.4 \%)$ & $588(64.7 \%)$ & 2.16 \\
\hline $\begin{array}{l}\text { Attended One } \\
\text { Session }\end{array}$ & $34(20.5 \%)$ & $109(14.7 \%)$ & $143(15.7 \%)$ & -1.17 \\
\hline $\begin{array}{l}\text { Attended More } \\
\text { than One Session }\end{array}$ & $37(22.3 \%)$ & $141(19.0 \%$ & $178(19.6 \%)$ & -.97 \\
\hline
\end{tabular}




\section{Varsity Athlete during Freshman Year (VARPLEBE)}

At the United States Naval Academy, a student faces many demands that are not typical for students at other institutions. In addition to academic demands, students are also faced with military requirements such as inspections, quizzes, and professional lectures. Although military demands are considerable, freshman who participate in varsity athletics face even more demands. While these student-athletes still complete all academic and military obligations, they must also meet the requirements of the sport in which they participate. Oftentimes, these student-athletes sacrifice up to three hours per day. For this reason, this variable (VARPLEBE) is closely related to two dependant variables: attrition and performance. Table 18 contains data on PIP participants, watchlist assignees, and the total population that participated in varsity athletics during their freshman year. An independent samples means test was conducted and produced a tvalue of -4.35 . As depicted in the table, PIP students are more represented on athletic teams during their plebe year than watch-list students.

Table 18. Varsity Athletics Participation during Plebe Year (AY2002-2005)

\begin{tabular}{|l|c|c|c|}
\hline & PIP (Percent) & $\begin{array}{c}\text { Watch-list } \\
\text { (Percent) }\end{array}$ & $\begin{array}{c}\text { Total } \\
\text { Population } \\
\text { (Percent) }\end{array}$ \\
\hline $\begin{array}{l}\text { Non Varsity } \\
\text { Athlete }\end{array}$ & $83(50 \%)$ & $503(67.7 \%)$ & $586(64.5 \%)$ \\
\hline $\begin{array}{l}\text { Varsity } \\
\text { Athlete }\end{array}$ & $83(50 \%)$ & $240(32.3 \%)$ & $323(35.5 \%)$ \\
\hline Total & $166(100 \%)$ & $743(100 \%)$ & $909(100 \%)$ \\
\hline
\end{tabular}

\section{E. RELATIONSHIP OF INDEPENDENT VARIABLES TO DEPENDANT VARIABLES}

\section{PIP Model}

To measure the differences between the two groups, the dependant variable is specified as a dichotomous dependant variable (1=PIP, $0=$ watch-list). A non-linear binomial logistic regression is used to predict assignment to PIP. Table 19 identifies the independent variables utilized in the model and their predicted impact on assignment to the PIP. 
Table 19. Independent Variables Utilized to Predict Assignment to the PIP (AY 2002-2005)

\begin{tabular}{|c|c|c|c|}
\hline \multicolumn{2}{|c|}{ Variable } & Variable Name & $\begin{array}{c}\text { Predicted } \\
\text { Effect }\end{array}$ \\
\hline \multicolumn{2}{|c|}{ SAT Math Scores } & SATMAVG & - \\
\hline \multicolumn{2}{|c|}{ SAT Verbal Scores } & SAMVAVG & - \\
\hline \multicolumn{2}{|l|}{ Female } & GENDER2 & $?$ \\
\hline \multirow[t]{3}{*}{ Ethnicity } & $\begin{array}{c}\text { African } \\
\text { American }\end{array}$ & AFRICANAMERICAN & + \\
\hline & Hispanic & HISPANIC & + \\
\hline & $\begin{array}{c}\text { Other } \\
\text { Ethnicities }\end{array}$ & OTHERETHNICITIES & + \\
\hline \multicolumn{2}{|c|}{$\begin{array}{l}\text { Recommendations of } \\
\text { the Admissions Board } \\
\text { (RAB) }\end{array}$} & RAB500 & + \\
\hline \multicolumn{2}{|c|}{$\begin{array}{l}\text { Whole Person } \\
\text { Multiple (WPM) }\end{array}$} & CM1000 & - \\
\hline \multicolumn{2}{|c|}{$\begin{array}{l}\text { Recruited Athlete } \\
\text { (Blue chip athlete) }\end{array}$} & BLUE & - \\
\hline
\end{tabular}

Of the variables included in the model, it is hypothesized that some are more likely to predict assignment to the PIP. SAT scores, both math and verbal, are likely to determine if a student is assigned to the program. In particular, SAT math scores are believed to be extremely important at predicting academic success at the Naval Academy. Additionally, due to the nature of the technical aspect of core courses at the Naval Academy, performance on SAT math is viewed as a predictor. As a result, lower performance on the SAT math will cause a student to be assigned to the PIP. Students with low whole person multiples are also likely to be assigned to the PIP. Another group that is more likely to be assigned to PIP is recruited athletes. Because recruited athletes comprise $50 \%$ of the PIP, it is hypothesized that they are more likely to be assigned to the program. Conversely, ethnicity is not believed to be a good predictor for inclusion in the 
PIP. Based on the descriptive statistics previously discussed, it does not appear likely that ethnic differences will cause a student to be more likely assigned to the program. Students with high RABs are not believed to be more likely to be assigned to the program because they have demonstrated a certain quality to the Admissions Board that makes them less likely to require additional assistance. Finally, gender is variable that is difficult to predict. Because females comprise equitable percentages within the PIP and the watch-list, it is difficult to predict if they are more likely to be assigned to the program.

\section{Attrition Model}

To measure the impact of independent variables on a students' reason for attrition during his or her freshman year, a Three-Way Non-Linear (Trinomial Logistic) model is specified. The values of the dependant variables are voluntary attrition, academic attrition, and (the reference category) remained until sophomore year. Table 20 identifies the independent variables utilized in the model to predict attrition for academic reasons and voluntary reasons and their hypothesized effects. 
Table 20. Predicted Effect of Independent Variables Utilized to Measure Attrition (AY2002-2005)

\begin{tabular}{|c|c|c|c|c|}
\hline \multicolumn{2}{|c|}{ Variable } & Variable Name & $\begin{array}{c}\text { Attrite: } \\
\text { Academic }\end{array}$ & $\begin{array}{c}\text { Attrite: } \\
\text { Voluntarily }\end{array}$ \\
\hline \multicolumn{2}{|c|}{$\begin{array}{l}\text { Difference in final course grade from six- } \\
\text { week to final grade in core courses }\end{array}$} & AVGDIF & - & - \\
\hline \multicolumn{2}{|c|}{ Average six-week grade in core courses } & AVG6WK & + & + \\
\hline \multicolumn{2}{|c|}{ SAT Math Scores } & SATMAVG & + & + \\
\hline \multicolumn{2}{|c|}{ SAT Verbal Scores } & SAMVAVG & + & + \\
\hline \multicolumn{2}{|c|}{ Attended One or Less MGSP Sessions } & MSGONE & ? & ? \\
\hline \multicolumn{2}{|c|}{ Attended Two or More MGSP Sessions } & MSGTWOMO & + & + \\
\hline \multicolumn{2}{|c|}{$\begin{array}{l}\text { Participated in Varsity Athletics During } \\
\text { Freshman Year }\end{array}$} & VARPLEBE & - & + \\
\hline \multicolumn{2}{|l|}{ Female } & GENDER2 & ? & - \\
\hline \multirow[t]{3}{*}{ Ethnicity } & African American & AFRICANAMERICAN & ? & ? \\
\hline & Hispanic & HISPANIC & ? & ? \\
\hline & Other Ethnicities & OTHERETHNIC & ? & ? \\
\hline \multicolumn{2}{|c|}{ Participant in PIP } & PIP & - & - \\
\hline
\end{tabular}

\section{a. Academic Attrition}

Of the variables selected, academic performance and academic assistance programs will have the greatest impact on whether one will attrite for academic reasons. If students have poor academic performance (difference between six-week and final grade), then he or she is more likely to attrite for academic reasons. In addition, if students seek additional academic assistance, it is hypothesized that they are less likely to attrite for academic reasons. Students who only attend one MGSP session, however, are not deemed as an active participant and, as a result, it is unclear if the program will have an effect on these students. Factors such as gender and ethnicity are not believed to effect persistence to any significant degree. Finally, if a student is enrolled in PIP, it is believed that he or she is more likely to attrite for academic reasons for the simple fact that they represent those students who were admitted with the lowest qualifications. 


\section{b. Voluntary Attrition}

The hypothesized effect of independent variables on whether or not a student persists to his or her sophomore year are largely based on social factors. It is believed that those students who are actively involved in group activities are more likely to persist. For example, students who play sports and/or involve themselves in MGSP are more likely to develop a support network that will aid them in their adjustment to college. Conversely, it is hypothesized that females are more likely to attrite for voluntary reasons because they may not be able to establish strong support networks due to the overrepresentation of males at the Naval Academy. Academically, it is hypothesized that those who struggle will be more likely to attrite for voluntary reasons. For this reason, variables of an academic nature (grades and SAT scores) are more likely to predict attrition for voluntary reasons. Included in this category are PIP participants. Because it is believed that they are more likely to struggle academically, it is believed that they are more likely to leave for voluntary reasons. Finally, the impact of ethnicity is undeterminable.

\section{Performance Differences}

To measure the impact of selected independent variables on performance during a student's freshman year at the United States Naval Academy, an Ordinary Least Squares Model is utilized. The dependant variable was the average difference in performance from the six-week point in a course to the final grade that was awarded. Table 21 identifies the independent variables utilized in the model and the predicted effect. 
Table 21. Independent Variables Utilized to Predict Effect on Differences Between Six-week Grades and Final Grade Awarded (AY2002-2005)

\begin{tabular}{|c|c|c|c|}
\hline \multicolumn{2}{|c|}{ Variable } & Variable Name & Effect: Performance \\
\hline \multicolumn{2}{|c|}{ Average six-week grades } & AVG6WK & + \\
\hline \multicolumn{2}{|c|}{ SAT Math Scores } & SATMAVG & + \\
\hline \multicolumn{2}{|c|}{ SAT Verbal Scores } & SAMVAVG & + \\
\hline \multicolumn{2}{|c|}{$\begin{array}{l}\text { Participated in one or less MGSP } \\
\text { sessions }\end{array}$} & MSGONE & $?$ \\
\hline \multicolumn{2}{|c|}{$\begin{array}{l}\text { Participated in two or more } \\
\text { MGSP sessions }\end{array}$} & MSGTWOMO & + \\
\hline \multicolumn{2}{|c|}{ Participated in Varsity Athletics } & VARPLEBE & - \\
\hline \multicolumn{2}{|l|}{ Female } & GENDER2 & ? \\
\hline \multirow[t]{3}{*}{ Ethnicity } & $\begin{array}{l}\text { African } \\
\text { American }\end{array}$ & AFRICANAMERICAN & ? \\
\hline & Hispanic & HISPANIC & $?$ \\
\hline & Other Ethnicities & OTHERETHNIC & ? \\
\hline \multicolumn{2}{|c|}{ Participant in PIP } & PIP & - \\
\hline
\end{tabular}

In this model, it is hypothesized that those students with the higher academic entry scores (SAT) are more likely to perform better throughout a given course. Similarly, those who seek additional academic assistance are more likely to improve in their performance. It is uncertain, however, if participation in only one MGSP session will produce any improvement in a given course. It is also believed that students participating in athletics will experience greater academic difficulties than non-athletes due to the commitment that these students make to the sport in which they participate. Finally, it is unclear whether or not a student's ethnicity or gender will impact his or her academic performance.

\section{F. QUALITATIVE DATA}

An exploratory survey was administered to PIP participants from AY 2002-2005. The purpose of the survey was to measure motivation and attempt to identify 
characteristics of at-risk students who leads to persistence. The survey was administered to all 130 students at the Naval Academy who participated in the PIP. The survey was not administered to the 36 students who failed to persist at the Naval Academy beyond their freshman year. Of the 130 students surveyed, 100 students responded (76.92\%). Results of the survey are contained in Appendix A.

There were 23 questions on the survey. Of the 23 questions, 13 were scored using a Likert Scale. The remaining 10 questions required students to select an answer that best described their attitude. If a selection was not available that reflected their attitude, they provided additional text.

Closely modeled after the College Student Inventory (CSI), the survey measures a student's motivation in the following areas: academics, coping skills, social influences, and receptivity to support services. In addition to measuring a student's motivation in each of these areas, additional questions were posed to evaluate the current academic assistance programs available to at-risk students at the Naval Academy. Table 22 outlines the number of questions that were asked in a particular category.

Table 22. Motivation Survey: Number of Questions per Category

\begin{tabular}{|l|c|}
\hline \multicolumn{1}{|c|}{ Category } & Number of Questions \\
\hline Academic Motivation & 3 \\
\hline Coping Skills & 5 \\
\hline Social Motivation & 6 \\
\hline Receptivity to Support Services & 4 \\
\hline $\begin{array}{l}\text { Evaluation of Current Academic } \\
\text { Assistance Programs }\end{array}$ & 5 \\
\hline
\end{tabular}


THIS PAGE INTENTIONALLY LEFT BLANK 


\section{DATA ANALYSIS}

The results of three models are discussed in this chapter. The first model analyzes the differences between students selected for inclusion in the PIP and those who were assigned to the watch-list. The second model analyzes the impact of selected independent variables on at-risk student attrition at the Naval Academy. Finally, the third model analyzes the impact of selected independent variables on student performance in core courses. In all models, SPSS 11.0 is utilized. The results of the models are contained in Appendix B.

In addition, results of survey data are discussed. Where appropriate, survey data is used to elucidate the findings in the quantitative analysis. Case processing summaries for each model are provided in tables throughout the chapter. Results from each of the models are discussed in their respective sections.

\section{A. PIP PREDICTION MODEL (PIP AS DEPENDANT VARIABLE)}

In this model (logistic regression), the dependant variable is whether or not a student is selected to participate in PIP. Control variables include demographic information. The explanatory variables include: SAT math averages, SAT verbal averages, gender, ethnicity, whole person multiple, recommendations of the Admissions Board (RAB), and whether or not a student is a recruited (blue chip) athlete. Thus, the model is specified as follows:

$$
\begin{gathered}
\text { PIP }=f \text { (SAT math average, SAT verbal average, gender, ethnicity, whole } \\
\text { person multiple, RAB, and recruited athlete })
\end{gathered}
$$

The -2 Log likelihood is 765.91. The model had a Chi-square value of 84.58 with a significance level of .000. Table 23 contains the coefficient and significance levels for each of the independent variables (predictors). Of the seven independent variables used in the model, four were significant at the five percent or better level. The cut value for the model is .184. 
Table 23. Logistic Regression Results (PIP as Dependant Variable)

\begin{tabular}{|l|c|c|}
\hline \multicolumn{1}{|c|}{ Variable } & Coefficient & Significance \\
\hline SAT Verbal & .002 & .281 \\
\hline SAT Math & -.012 & .000 \\
\hline Gender & -.009 & .971 \\
\hline African American & -.020 & .938 \\
\hline Hispanic & -.149 & .616 \\
\hline Other Ethnicity & -.328 & .526 \\
\hline RAB500 Person & -.062 & .047 \\
\hline Whole & -.100 & .021 \\
Multiple & .925 & .000 \\
\hline Recruited Athlete & & \\
\hline
\end{tabular}

\section{Discussion of Variables}

a. SAT Math

A student's SAT math scores is significant at the one percent level. This indicates that students with lower SAT math scores are more likely to be assigned to the PIP. Table 24 indicates that the 32-point difference in SAT math scores is significant and is a major factor used to select at-risk students for academic assistance.

Table 24. Mean SAT Math Averages (AY2002-2005)

\begin{tabular}{|l|l|l|}
\hline & PIP & Watch-list \\
\hline Valid N & 166 & 743 \\
\hline SAT Math Average & 544 & 576 \\
\hline
\end{tabular}

\section{b. Recommendations of the Admissions Board}

Students with lower RAB scores are more likely to be assigned to the PIP.

As discussed in an earlier chapter, students assigned to PIP represent those students with the lowest entry characteristics. Therefore, it is logical that they would also have low RAB scores. 


\section{c. Whole Person Multiple}

Students with higher whole person multiples are less likely to be assigned to the PIP. Similarly with the RAB scores, students who have high WPM represent the most competitive students at the Naval Academy and have stellar performance records. Therefore, it is logical that those with high WPM would not be assigned to PIP. This variable is significant at the five percent level. Table 13 describes the mean whole person multiple of each of the groups.

\section{d. $\quad$ Recruited Athletes}

Recruited athletes are more likely to be assigned to the PIP than nonrecruited athletes. This variable is significant at the one percent level. As reported earlier, PIP is composed of far more recruited athletes than the watch-list (50\% to 30\%).

In conclusion, the results of the model indicate four major differences between those students assigned to the PIP as opposed to those assigned to the watch-list. The following list characterizes students assigned to the PIP:

- $\quad$ They have significantly lower SAT math scores.

- $\quad$ They have lower RAB scores than those assigned to the watch-list.

- $\quad$ They have lower WPM than those assigned to the watch-list.

- $\quad$ Students assigned PIP are much more likely to be recruited athletes.

\section{B. ATTRITION MODEL (REASON FOR LEAVING AS DEPENDANT VARIABLE)}

In this model (three-way non-linear regression), the dependant variable is a student's reason for leaving the Naval Academy. The dependant variable consists of three categories: persist to sophomore year, attrites for academic reasons, and attrites for voluntary reasons. Control variables include demographic variables as well as other variables that are believed to be correlated with attrition. The control variables are: average difference between six-week grade and final grade, average six-week grades, SAT math averages, SAT verbal averages, whether a student participated in one or less MGSP session, whether or not a student participated in two or more MGSP sessions, 
whether or not a student is an athlete during his or her plebe year, gender, ethnicity, and whether or not a student is assigned to the PIP. Thus, the model is specified as follows:

Reason for Leaving (Persisted to sophomore year, attrite for academic reasons, or attrite for voluntary reasons) $=f$ (average difference between six-week grade and final grade, average six-week grades, SAT math averages, SAT verbal averages, whether a student participated in one or less MGSP session, whether or not a student participated in two or more MGSP sessions, whether or not a student is an athlete during his or her plebe year, gender, ethnicity, and whether or not a student is assigned to the PIP)

The -2 Log likelihood is 472.42 . The model had a Chi-square value of 96.724 with a significance level of .000 . Table 25 contains the coefficient and significance levels for each of the independent variables (predictors) in explaining the reasons for which a student voluntarily attrites. Table 26 contains the coefficient and significance levels for each of the independent variables (predictors) in explaining the reasons for which a student attrites due to academic difficulties. In explaining why a student attrites due to voluntary reasons, five of the twelve variables are significant; four are significant at the five percent level and one is significant at the ten percent level. In explaining why a student attrites due to academic reasons, four of the twelve variables were significant at the five percent level. 
Table 25. Attrite for Voluntary Reasons (Trinomial Regression Results)

\begin{tabular}{|l|c|c|}
\hline \multicolumn{1}{|c|}{ Variable } & Coefficient & Significance \\
\hline Average Difference in Six-Week Grade and & & \\
Final Grade & -.873 & .018 \\
\hline Average Six-Week Grade & -.794 & .003 \\
\hline SAT Verbal & .002 & .454 \\
\hline SAT Math & .000 & .958 \\
\hline Participated in one MGSP Session & .157 & .695 \\
\hline Participated in two or more MGSP Session & -.943 & .051 \\
\hline Participated in varsity athletics during plebe year & -.279 & .444 \\
\hline Gender & 1.328 & .000 \\
\hline African American & -.923 & .159 \\
\hline Hispanic & .219 & .651 \\
\hline Other Ethnicity & -1.055 & .322 \\
\hline Assigned to PIP & -1.526 & .022 \\
\hline
\end{tabular}

1. Discussion of Variables: Attrite Voluntarily

a. Average Difference in Six-Week Grade and Final Grade

Students with a large improvement from the six-week point in a course to the final grade are less likely to attrite. This variable is significant at the five percent level (.018).

\section{b. $\quad$ Average Six-Week Grade}

Students with higher six-week averages are less likely to attrite for voluntary reasons than those with high six-week grades. This variable is significant at the five percent level (.003). In general, students who are more successful in their academics are less likely to leave the Naval Academy due to voluntary reasons.

\section{c. Participated in Two or More MGSP Sessions}

Students who are active participants in the MGSP are less likely to attrite for personal reasons. This variable is significant at the ten percent level. It is interesting to note that students who only participate in one or less MGSP session are not less likely to attrite for personal reasons. Similar to academic success as a predictor for persistence, the significance of participation in MGSP indicates that students who become active participants in the learning process are much more likely to persist beyond their freshman year. 


\section{d. Gender}

Women are more likely to attrite for personal reasons than men. This variable is significant at the five percent level (.000). In addition, the relatively large logit coefficient indicates that women may face significant hurdles to adjusting to a predominately male, military institution.

\section{e. $\quad$ Assigned to PIP}

Students assigned to PIP are less likely to attrite for personal reasons than other at-risk students not assigned to PIP. This variable is significant at the five percent level (.022). Again, the relatively large logit coefficient suggests that a major benefit of the PIP is assisting at-risk students to adjust to the rigors of their freshman year at the Naval Academy.

Table 26. Attrite for Academic Reasons (Trinomial Regression Results)

\begin{tabular}{|l|c|c|}
\hline \multicolumn{1}{|c|}{ Variable } & Coefficient & Significance \\
\hline $\begin{array}{l}\text { Average Difference in Six-Week Grade and } \\
\text { Final Grade }\end{array}$ & -1.337 & .000 \\
\hline Average Six-Week Grade & -1.462 & .000 \\
\hline SAT Verbal & -.001 & .817 \\
\hline SAT Math & .005 & .168 \\
\hline Participated in one MGSP Session & -.510 & .239 \\
\hline Participated in two or more MGSP Session & -1.420 & .008 \\
\hline Participated in varsity athletics during plebe year & -.450 & .250 \\
\hline Gender & -.278 & .606 \\
\hline African American & .190 & .725 \\
\hline Hispanic & 1.254 & .007 \\
\hline Other Ethnicity & .314 & .698 \\
\hline Assigned to PIP & .371 & .404 \\
\hline
\end{tabular}

\section{Discussion of Variables: Attrite for Academic Reasons}

\section{a. Average Differences in Six-Week Grade and Final Grade}

Students who had significant positive change in their grades from the sixweek mark to their final grade are less likely to attrite for academic reasons. This variable is significant at the five percent level (.000).

\section{b. Average Six-Week Grade}

Students with higher six-week grades are less likely to attrite for academic reasons. This variable is significant at the five percent level (.000). As reported 
previously, the significance level of this variable indicates the importance of academic success in a student's persistence beyond the freshman year.

\section{c. Participation in Two or More MGSP Sessions}

Students who participate in two or more MGSP sessions are less likely to attrite for academic reasons than those who do not participate in MGSP. This variable is significant at the five percent level (.008). In addition, the relatively large logit coefficient is indicative of the importance of attending special tutorials offered by senior Midshipmen. In past studies measuring the impact of supplemental instruction, the issue of motivation has confounded many of the studies. Survey results of PIP students from AY 2002-2005 indicate that at-risk students who persisted are very motivated. Of the responders, 87\% reported that they had sought additional academic assistance. Although those who attrited were not surveyed, it is compelling that those who are most at-risk (PIP participants) had voluntarily sought additional assistance to such a degree.

\section{d. Ethnic Minorities}

Only Hispanic students are more inclined to attrite for academic reasons compared to Caucasians. This variable is significant at the five percent level (.007).

\section{e. Assigned to PIP}

It is interesting to note that the most at-risk students at the Naval Academy are not more inclined to attrite due to academic reasons. Though not statistically significant, it is interesting that they are not more vulnerable given the dramatic differences between PIP participants and watch-list assignees. In a survey that is administered to PIP participants, 56 percent of responders indicated that the personal attention from the Academic Center staff is the most positive aspect of the PIP program. Though it can only be inferred, the attention that these students receive from the Academic Center, undoubtedly, has a positive effect on their persistence at the Naval Academy. 


\section{PERFORMANCE MODEL (DIFFERENCE FROM SIX-WEEKGRADE TO FINAL GRADE AS DEPENDANT VARIABLE)}

In this model (Ordinary Least Squares), the dependant variable is the difference in a student's grades from the six-week point in a course to the final grade that is awarded. Control variables included demographic variables as well as other variables that were believed to be correlated with academic performance. These variables include: average six-week grades, SAT math averages, SAT verbal averages, whether a student participated in one or less MGSP session, whether or not a student participated in two or more MGSP sessions, whether or not a student is an athlete during his or her plebe year, gender, ethnicity, and whether or not a student is assigned to the PIP. Thus, the model is specified as follows:

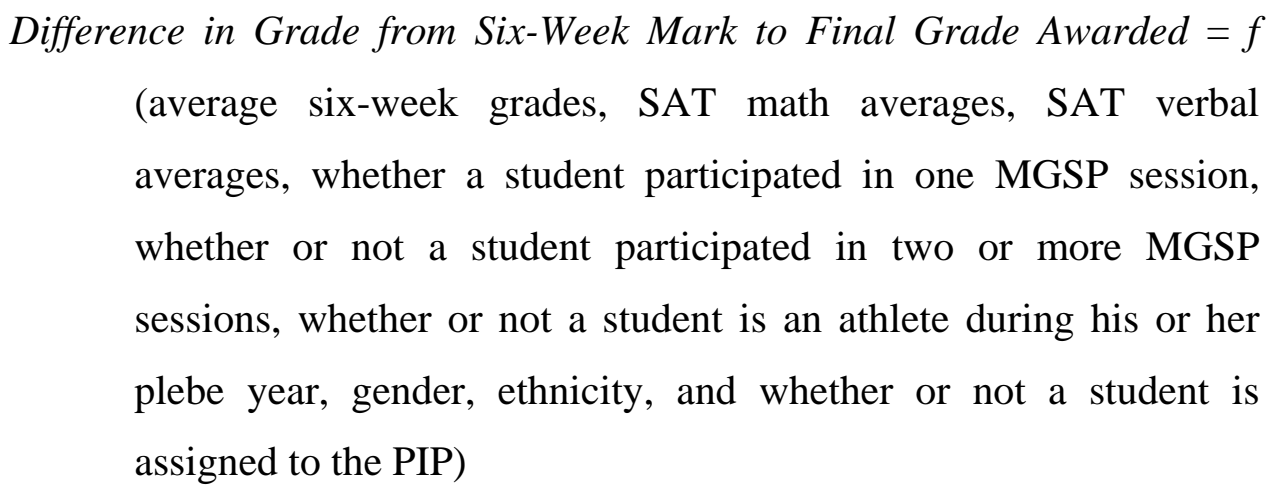

The $\mathrm{R}^{2}$ value is .177 . This value indicates that the model explains only $18 \%$ of the variation. The F-value for the model is 10.969. The significance of the model is .000. Table 27 contains the coefficient, T-statistics, and significance levels for each of the independent variables (predictors). Of the eleven independent variables used in the model, five are significant. Four variables are significant at the five percent level and one is significant at the ten percent level. 
Table 27. Performance Model (Difference in Six-Week Grade and Final Grade Awarded as Dependant Variable)

\begin{tabular}{|l|c|c|c|}
\hline \multicolumn{1}{|c|}{ Variable } & Coefficient & T-Statistic & Significance \\
\hline Average Six-Week Grade & -.242 & -8.971 & .000 \\
\hline SAT Verbal & $-2.61 \mathrm{E}-04$ & -.827 & .409 \\
\hline SAT Math & $1.11 \mathrm{E}-03$ & 2.998 & .003 \\
\hline Participated in one MGSP Session & $7.02 \mathrm{E}-03$ & .148 & .882 \\
\hline $\begin{array}{l}\text { Participated in two or more MGSP } \\
\text { Session }\end{array}$ & .111 & 2.490 & .013 \\
\hline $\begin{array}{l}\text { Participated in varsity athletics during } \\
\text { plebe year }\end{array}$ & $3.16 \mathrm{E}-03$ & .080 & .936 \\
\hline Gender & $-6.13 \mathrm{E}-02$ & -1.19 & .235 \\
\hline African American & $-8.94 \mathrm{E}-02$ & -1.614 & .107 \\
\hline Hispanic & -.160 & -2.771 & .006 \\
\hline Other Ethnicity & -.161 & -1.874 & .062 \\
\hline Assigned to PIP & -6.984 & -1.354 & .176 \\
\hline
\end{tabular}

\section{Discussion of the Variables}

a. Average Six-Week Grade

Students with lower six-week grades achieved a gain in grades over the course of the semester. As reported previously, the average change in grade for the total population was -0.17 (on a 4.0 grade point scale). This variable is significant at the five percent level (.000).

\section{b. SAT Math Score}

Students with higher SAT math scores improved their performance from the six-week period of a course until the end of the course. This variable is significant at the five percent level (.003).

\section{c. Participated in Two or More MGSP Sessions}

These students improved their grades from the six-week period of the course to the end of the course. This variable is significant at the five percent level (.013). This variable is interesting because the nature of supplemental instruction is that improvement in a particular course is realized after attending multiple sessions. In other words, students who attend only one MGSP session show no improvement in grades. According to the model, students who attended two or more MGSP sessions averaged an increase in grade of .11. This is especially significant in that the total population experienced a decrease of -.17. Similarly to the findings in other models previously 
reported, students who attend MGSP on a regular basis will experience an increase in their performance.

\section{d. Ethnic Minorities}

Only Hispanic students are less likely to experience positive improvement from the six-week period in a course until the end of the course compared to Caucasians. This variable is significant at the five percent level (.006).

\section{SURVEY RESULTS}

Students who were surveyed represented a group of at-risk students who persisted beyond their freshmen year. As such, their motivation can be assumed to be different than those who failed to persist. The survey measured motivation in four areas: academic motivation, coping skills, social motivation, and receptivity to support services. An additional category is created to elicit information about current academic assistance programs available for at-risk students at the Naval Academy.

\section{Academic Motivation}

Three questions specifically addressed academic motivation. On all three questions, students provided responses that are indicative of high academic motivation. Table 28 is a summary of selected statistics from questions concerning academic motivation. It is interesting to note that only three percent of responders arrived at the Naval Academy with no academic goals. Similarly, it is very interesting that 90 percent of responders had academic goals of achieving a 2.5 or higher Grade Point Average. This is significant for three reasons: first, the Naval Academy is a very difficult academic institution and achieving academic success is challenging; second, the minimum requirement for graduation is a $2.0 \mathrm{GPA}$; third, all of these students represent the most at-risk students admitted to the institution and yet they have lofty academic goals. 
Table 28. Selected Responses from Survey Data (Academic Motivation)

\begin{tabular}{|l|c|}
\hline \multicolumn{1}{|c|}{ Academic Motivation } & Percent \\
\hline Arrived at the Naval Academy with goals of achieving a 2.5 GPA or higher & $90 \%$ \\
\hline Arrived at the Naval Academy with no academic goals & $3 \%$ \\
\hline Aspires to earn Master's degree or higher & $82 \%$ \\
\hline Is satisfied with only earning a Bachelor's degree & $18 \%$ \\
\hline
\end{tabular}

\section{Coping Skills}

At-risk students manage their learning in different ways. As per the literature review, many at-risk students fail to fully understand the manner in which they learn best. At the Naval Academy, at-risk students who persisted appear to have developed successful coping strategies that have allowed them to succeed and persist. Table 29 is a summary of selected statistics from questions concerning coping skills. It is interesting to note that 51 percent of at-risk students believe that additional studying will lead to an improvement in performance. In other studies, researchers have found the opposite to be true. Because at-risk students have experienced academic difficulty so frequently, they believe that it is inevitable that they will perform poorly, regardless of effort.

Table 29. Selected Responses from Survey Data (Coping Skills)

\begin{tabular}{|c|c|}
\hline \multicolumn{1}{|c|}{ Coping Skills } & Percent \\
\hline $\begin{array}{c}\text { Voluntarily sought academic assistance } \\
\text { required to do so }\end{array}$ & $78 \%$ \\
\hline Willingness to interact with professors & $5 \%$ \\
\hline $\begin{array}{c}\text { Believes that additional studying improves } \\
\text { performance }\end{array}$ & $51 \%$ \\
\hline
\end{tabular}

\section{Social Motivation}

Many at-risk students fail to balance social opportunities with academic requirements. In college, this is compounded by the fact that there are fewer controls than during a student's high school career. In college, students must possess selfdiscipline in order to harmonize social opportunities and academic requirements. For the students surveyed, they appear to have found a healthy balance between socializing and studies. Table 30 is a summary of selected statistics from questions concerning social motivation. Of the students surveyed, 64\% reported that they routinely complete 
academic requirements instead of participating in extra-curricular activities. In addition, not a single responder indicated that he or she routinely choose to participate in extracurricular activities at the expense of his or her academic requirements.

Table 30. Selected Responses from Survey Data (Social Motivation)

\begin{tabular}{|l|c|}
\hline \multicolumn{1}{|c|}{ Social Motivation } & Percent \\
\hline Maintain healthy balance between non-academic activities and academic requirements & $71 \%$ \\
\hline Allow non-academic activities to take precedence over academic requirements & $7 \%$ \\
\hline $\begin{array}{l}\text { Routinely complete academic requirements instead of participating in extra-curricular } \\
\text { activities }\end{array}$ & $64 \%$ \\
\hline $\begin{array}{l}\text { Routinely chooses to participate in extra-curricular activities instead of fulfilling } \\
\text { academic requirements }\end{array}$ & $0 \%$ \\
\hline
\end{tabular}

\section{Receptivity to Support Services}

As discussed in the literature review, many at-risk students do not succeed because they fail to seek assistance. Table 31 is a summary of selected statistics from questions concerning coping skills. It is interesting to note that 59 percent of at-risk students were willing participants in the PIP. Similarly, it is also interesting that only three percent did not want to participate in the program.

\section{Table 31. Selected Responses from Survey Data (Receptivity to Support Services)}

\begin{tabular}{|l|c|}
\hline \multicolumn{1}{|c|}{ Receptivity to Support Services } & Percent \\
\hline Believed that they would need academic assistance & $56 \%$ \\
\hline Is a willing participant in the PIP & $59 \%$ \\
\hline Is not a willing participant in the PIP & $3 \%$ \\
\hline
\end{tabular}

\section{Evaluation of Academic Assistance Programs}

Included in the survey is a series of questions that allowed responders to evaluate two academic assistance programs at the Naval Academy: the PIP and MGSP. Table 32 summarizes the evaluation of the PIP. Table 33 summarizes the evaluation of the MGSP.

\section{a. PIP}

Students in the PIP believe that the relationships formed with the academic advisors are crucial to the program's success. In addition, many enrolled in the program enjoy that the focus is on general study skills. Similarly, however, a percentage 
of responders believe that the program could be improved if more content-specific instruction could be provided.

Table 32. Summary of PIP Evaluation

\begin{tabular}{|l|c|}
\hline \multicolumn{1}{|c|}{ PIP } & Percent \\
\hline $\begin{array}{l}\text { Strength of the program is the relationship formed with } \\
\text { academic adviser }\end{array}$ & $56 \%$ \\
\hline The program is helpful because it focuses on general study skills & $32 \%$ \\
\hline A weakness in the program is that it is not content specific & $39 \%$ \\
\hline The schedule of the program is not convenient & $27 \%$ \\
\hline
\end{tabular}

\section{b. MGSP}

Although some responders believe that the program improves performance, others do not. It is interesting to note, however, that the quantitative analysis of the data indicates that continued participation in MGSP sessions improves performance and also increases the likelihood of persistence. Other responders indicated that they thought the MGSP leaders were effective, while others believed that the quality of the MGSP leaders needs to improve.

Table 33. Summary of MGSP Evaluation

\begin{tabular}{|l|c|}
\hline \multicolumn{1}{|c|}{ MGSP } & Percent \\
\hline $\begin{array}{l}\text { Program could be improved if more instructors were available at } \\
\text { individual sessions }\end{array}$ & $12 \%$ \\
\hline Program assists in improving academic performance & $33 \%$ \\
\hline Program does not improve my academic performance & $28 \%$ \\
\hline MGSP leaders are effective & $16 \%$ \\
\hline Competency of instructors needs to improve & $10 \%$ \\
\hline Environment of MGSP should be improved (location, frequency) & $17 \%$ \\
\hline
\end{tabular}


THIS PAGE INTENTIONALLY LEFT BLANK 


\section{CONCLUSIONS AND RECOMMENDATIONS}

\section{A. RESULTS}

The primary goal of this thesis is to examine the impact of academic assistance programs at the United States Naval Academy on at-risk students. Three areas were explored: the characteristics of at-risk students, the effect of academic assistance programs on at-risk retention and persistence, and the impact of academic assistance programs on at-risk academic performance. The following section provides analysis on the four primary research questions that were posed earlier in the thesis.

1. What are the differences between students selected for inclusion in the PIP as opposed to those assigned to the watch-list?

According to the model, the fundamental differences in those who are assigned to the PIP compared with those assigned to the watch-list include: lower SAT math scores, lower RAB scores, lower WPM scores, and PIP participants are much more likely to be recruited athletes than watch-list students.

2. What is the impact of selected academic assistance programs on whether or not an at-risk student attrites at the Naval Academy during his or her freshman year?

According to the second model, at-risk students who participate in the PIP at the Naval Academy are less vulnerable to attrition than those who do not. In addition, students who regularly participate in MGSP sessions are much more likely to persist to their sophomore year than those who do not.

\section{Do students solely enrolled in PIP experience greater academic improvement than other PIP students who also participate in MGSP?}

According to the third model, students who participate in MGSP, regardless of enrollment in other academic assistance programs, perform better academically. It should also be noted, however, that regular attendance in MGSP sessions is critical to a student's improvement. 


\section{What is the impact of motivation on the performance of at-risk students?}

The students who were surveyed represent the most at-risk students at the Naval Academy. It is clear that their persistence is due to their successful motivation in the following areas: academic motivation, coping skills, social motivation, and receptivity to support services.

\section{B. RECOMMENDATIONS}

The results of the research indicate that at-risk students at the Naval Academy are capable of achieving academic success if provided with appropriate levels of assistance. Although existing programs are successful, there are a number of changes and/or modifications that can be made to improve the retention and academic performance of atrisk students.

\section{Motivation Survey}

Although the current admissions process at the Naval Academy should be continued, there is one significant change that must be made: at-risk students must be surveyed prior to being accepted. The results of the survey indicate that the group of atrisk students still in attendance at the Naval Academy represent highly motivated learners. It is impossible to characterize students who attrited as "unmotivated" because they were not available to be surveyed. It is possible, however, to assume that students who attrited were less motivated than those who persisted. As part of the admissions process at the Naval Academy, applicants with questionable entrance qualifications (i.e., candidates for the PIP) should be subject to an academic motivation survey prior to acceptance. It only makes sense that the Naval Academy afford the opportunity to attend the institution to those who are committed. There exist a number of academic motivation surveys that could be administered to applicants in a timely manner. Although there is a cost associated with administering the survey, these costs represent only a fraction of the cost of one student who attrites.

\section{Continue PIP}

As an academic assistance program, the PIP is a very successful program. The support that the at-risk students receive from the Academic Center staff is unquestionably positive and has a tremendous impact on retention. Although PIP students represent the 
most susceptible students at the Naval Academy, they are no more likely to attrite than others with higher qualifications (watch-list students). Although the quantitative analysis indicates as much, it is the results of the survey that clearly demonstrate the impact of the program.

\section{Mandate MGSP for At-Risk Students}

Although the PIP is a successful program, it must be modified to include mandatory MGSP attendance. The results of the quantitative analysis clearly indicate that students who are active participants in the program are far more likely to persist. In addition, regular attendance at MGSP sessions leads to academic improvement. The PIP can become a very effective program if it maximizes the MGSP.

\section{Improve MGSP Leaders}

On a whole, MGSP is a very successful program and must be expanded. Results of the quantitative analysis indicate that regular attendance leads to an improvement in academic performance for all students, let alone at-risk students. Despite the success of the program, there are changes that need to be made to the program. Survey results indicate that MGSP leaders must be improved. Despite the fact that there already exists an extensive MGSP development program, perhaps even more of an emphasis on leader development must occur. Additional data should be collected to determine the appropriate changes to be made to the leadership development aspect of the program.

\section{RECOMMENDATIONS FOR FUTURE RESEARCH}

This thesis examined the impact of academic assistance programs on at-risk students at the Naval Academy. Although results were revealed, there arose a number of topics that could be explored through future research.

- $\quad$ Repeat the study using the entire brigade of Midshipmen. This study analyzed only those students selected for the PIP and the watch-list. It is unclear if the results would remain consistent if analyzing the larger population.

- $\quad$ MGSP, despite its proven success, is largely unattended by the majority of students. Those who do attend, do not appear to attend with much regularity. It is proven, however, that regular attendance significantly improves academic performance. Future research could analyze 
Midshipmen views toward MGSP in determining whether or not one chooses to attend.

- In this study, only technical core courses were analyzed. Future research could analyze the academic improvement in other core courses. 


\section{APPENDIX A: ACADEMIC SURVEY}

\section{Academic Enthusiasm Survey}

This survey is designed to measure an individual's academic enthusiasm. Although each Midshipman that has received this survey has been personally selected based on his/her participation in the Plebe Intervention Program (PIP), your responses will be confidential.

1. When I arrived at the Naval Academy, I believed that I would need academic assistance.

1. Strongly Disagree $\mathbf{( 5 . 1 \% )}$

2. Disagree (19.2\%)

3. Neither Disagree or Agree (19.2\%)

4. Agree $\mathbf{( 3 9 . 4 \% )}$

5. Strongly Agree (17.2\%)

2. The three most beneficial aspects of the Plebe Intervention Program are:

a. Personal attention from my advisor. (43\%)

b. The focus of the program is on general study skills, not content specific matter. (32\%)

c. The relationships that are formed between me and my advisor. (13\%)

d. Other-(please specify) (12\%)

Trends: 1. Resources were available to help out struggling students ( 3 out of 12 responses).

\section{No benefit (5 out of 12 responses)}

3. The three least beneficial aspects of the Plebe Intervention Program are:

a. I do not like the personal attention. (7.1\%)

b. I do not like the advisors. (2.0\%)

c. The program does not focus on any particular courses. (38.8\%)

d. The schedule is not convenient for me. (26.5\%)

e. Other-(please specify) (25.5\%)

\section{Trends: 1 . Nothing consistent}

4. I have sought formal academic assistance (EI, MGSP, Tutoring)

1. When required by a professor, Company Officer, Coach, Officer Representative, or another authority figure. (5\%)

2. When suggested by a professor, Company Officer, Coach, Officer Representative, or another authority figure. (7\%)

3. Voluntarily (87\%)

4. Never (1\%)

5. When assigned to the Plebe Intervention Program, I welcomed the assistance. 1. Strongly Disagree (3\%) 
2. Disagree (13\%)

3. Neither Disagree or Agree (25\%)

4. Agree (41\%)

5. Strongly Agree (18\%)

6. I learn better in group settings.

1. Strongly Disagree (6\%)

2. Disagree $\mathbf{( 3 3 \% )}$

3. Neither Disagree or Agree (31\%)

4. Agree (23\%)

5. Strongly Agree (7\%)

7. When I arrived at the Naval Academy, my goals were:

1. $4.0(3 \%)$

2. $3.5-3.9(\mathbf{8 \%})$

3. $3.0-3.4(\mathbf{4 6 \% )}$

4. $2.5-2.9(33 \%)$

5. $2.0-2.4(\mathbf{7 \%})$

6. Under $2.0(\mathbf{0 \%})$

7. No goals (3\%)

8. My educational goals are:

1. Bachelor's degree (18\%)

2. Master's degree (69\%)

3. Doctorate degree $\mathbf{( 1 3 \% )}$

9. I have seriously contemplated leaving the Naval Academy...

1. Strongly Disagree (34\%)

2. Disagree (23\%)

3. Neither Disagree or Agree (15\%)

4. Agree (15\%)

5. Strongly Agree (13\%)

10. I find that group study sessions are productive.

1. Strongly Disagree (3\%)

2. Disagree (19.2)

3. Neither Disagree or Agree (30.3\%)

4. Agree $\mathbf{( 4 2 . 4 \% )}$

5. Strongly Agree (5.1\%)

11. I have found that increasing my academic effort greatly improves my academic performance.

1. Strongly Disagree (5\%)

2. Disagree (5\%)

3. Neither Disagree or Agree (16\%)

4. Agree $\mathbf{( 5 0 \% )}$ 


\section{Strongly Agree (24\%)}

12. Being involved in non-academic activities is more important to me than achieving academic excellence.

1. Strongly Disagree (15\%)

2. Disagree $\mathbf{( 2 5 \% )}$

3. Neither Disagree or Agree (35\%)

4. Agree (22\%)

5. Strongly Agree (3\%)

13. When managing my time, I typically:

1. Focus solely on my academic requirements and do not allow any distractions (social functions/ECA/Sports) to interfere. (11\%)

2. Do only what is academically required. (11\%)

3. Maintain a healthy balance between non-academic activities and academic requirements. (71\%)

4. Allow non-academic activities to take precedence over academic requirements. (7\%)

14. I have difficulty choosing to complete academic requirements instead of participating in athletic requirements.

1. Strongly Disagree (8\%)

2. Disagree (41\%)

3. Neither Disagree or Agree (31\%)

4. Agree (19\%)

5. Strongly Agree (1\%)

15. I have difficulty choosing to complete academic requirements instead of participating in extra-curricular activities.

1. Strongly Disagree (12\%)

2. Disagree (52\%)

3. Neither Disagree or Agree (27\%)

4. Agree (9\%)

5. Strongly Agree (0\%)

16. I have difficulty choosing to complete academic requirements instead of participating in military obligations.

1. Strongly Disagree (9\%)

2. Disagree (47\%)

3. Neither Disagree or Agree (27\%)

4. Agree (16\%)

5. Strongly Agree (1\%)

17. I tend to put off my assignments until they are due.

1. Strongly Disagree (11\%)

2. Disagree (28\%) 
3. Neither Disagree or Agree (17\%)

4. Agree (38\%)

5. Strongly Agree (6\%)

18. I feel free to interact with my professors.

1. Strongly Disagree (1\%)

2. Disagree (4\%)

3. Neither Disagree or Agree (10\%)

4. Agree $(\mathbf{6 4 \% )}$

5. Strongly Agree (21\%)

19. A lot of studying on my part does not improve my performance.

1. Strongly Disagree $(10 \%)$

2. Disagree $(41 \%)$

3. Neither Disagree or Agree (19\%)

4. Agree $(21 \%)$

5. Strongly Agree (9\%)

20. I have participated in the Midshipmen Study Group Program (MGSP) in the following courses (select more than one if applicable).

1. Chemistry I (79\%)

2. Chemistry II $(\mathbf{6 6 \%})$

3. Physics I (36\%)

4. Physics II (23\%)

5. Calculus I (38\%)

6. Calculus II $(\mathbf{2 3 \% )}$

7. Calculus III (21\%)

8. Other $\mathbf{( 8 \% )}$

21. If you have participated in MGSP, the three most appealing aspects of MGSP that caused me to participate are:

a. Environment (8.9\%)

b. Learning from peers $\mathbf{( 1 8 . 9 \% )}$

c. The MGSP Leader (15.6\%)

d. It assists in improving my academic performance. (33.3\%)

e. The location of the MGSP sessions are convenient. (6.7\%)

f. Other-(please specify) (16.7\%)

Trends: 1. Showed the instructor that the student was putting forth the effort (4 of 15 responses).

22. If you have not participated in MGSP, the three least appealing aspects of MGSP that caused me not to participate are:

a. I do not like the environment. (23.9\%)

b. I do not like learning from peers. (15.2\%)

c. It does not improve my academic performance. (28.3\%)

d. The location of the MGSP sessions are not convenient. (8.7\%) 


\section{f. Other- (please specify) (23.9\%)}

Trends: 1. None---only 8 responses.

23. The three changes that could be made to MGSP to increase participation are:

a.

b.

c.

Trends: $59 / 100$ respondents responded to this question.

Leaders:

1. Not enough per session (12 responses)

2. Competency of the instructors needs to improve (10 responses)

Lack Interaction Between Profs and MGSP Leader (5 responses)

Professors

1. Should be available at sessions (6 responses)

2. Should grant extra credit for attendance (6 responses)

Space/Environment

1. MGSP sessions should be in Bancroft Hall (7 responses)

2. MGSP sessions need to be offered more often (6 responses)

3. Snacks should be allowed/offered (4 responses) 
THIS PAGE INTENTIONALLY LEFT BLANK 


\section{APPENDIX B: SPSS OUTPUT}

\section{PIP Model (Logistic Regression)}

Case Processing Summary

\begin{tabular}{|l|l|c|c|}
\hline $\begin{array}{l}\text { Unweighted } \\
\text { Cases(a) }\end{array}$ & & N & Percent \\
\hline Selected Cases & $\begin{array}{l}\text { Included in } \\
\text { Analysis }\end{array}$ & 909 & 100 \\
\hline & Missing Cases & 0 & 0 \\
\hline & Total & 909 & 100 \\
\hline $\begin{array}{l}\text { Unselected } \\
\text { Cases }\end{array}$ & & 0 & 0 \\
\hline Total & & 909 & 100 \\
\hline
\end{tabular}

a. If weight is in effect, see classification table for the total number of cases

Dependent Variable Encoding

\begin{tabular}{|r|r|}
$\begin{array}{l}\text { Original } \\
\text { Value }\end{array}$ & $\begin{array}{l}\text { Internal } \\
\text { Value }\end{array}$ \\
\hline 0 & 0 \\
\hline 1 & 1 \\
\hline
\end{tabular}

Block 1: Method=Enter

Omnibus Tests of Model Coefficients

\begin{tabular}{|l|l|r|r|r|}
\hline & & $\begin{array}{c}\text { Chi- } \\
\text { square }\end{array}$ & \multicolumn{1}{c|}{ df } & \multicolumn{1}{c|}{ Sig. } \\
\hline Step 1 & Step & 88.28904 & 9 & $\begin{array}{r}3.55 E-~ \\
15\end{array}$ \\
\hline & & & & $\begin{array}{r}3.55 E- \\
15\end{array}$ \\
\hline & Block & 88.28904 & 9 & $3.55 E-$ \\
& & & & 15 \\
\hline
\end{tabular}

Model Summary

\begin{tabular}{|c|c|c|c|}
\hline Step & $\begin{array}{l}-2 \text { Log } \\
\text { likelihood }\end{array}$ & $\begin{array}{l}\text { Cox \& } \\
\text { Snell R } \\
\text { Square }\end{array}$ & $\begin{array}{l}\text { Nagelkerke } \\
\text { R Square }\end{array}$ \\
\hline 1 & 775.8801 & 0.09256 & 0.150866 \\
\hline
\end{tabular}


Classification Table (a)

\begin{tabular}{|l|l|r|r|r|r|}
\hline & Observed & & Predicted & & \\
\hline & & & PIP & & $\begin{array}{l}\text { Percentage } \\
\text { Correct }\end{array}$ \\
\hline Step 1 & PIP & 0 & 476 & 1 & \\
\hline & & 1 & 50 & 116 & 64.0646 \\
\hline & $\begin{array}{l}\text { Overall } \\
\text { Percentage }\end{array}$ & & & & 69.87952 \\
\hline
\end{tabular}

a. The cut value is . 180

Variables in the Equation

\begin{tabular}{|l|l|r|r|r|r|r|r|}
\hline & & \multicolumn{1}{l|}{ B } & \multicolumn{1}{l|}{ S.E. } & Wald & \multicolumn{1}{l|}{ df } & \multicolumn{1}{l|}{ Sig. } & \multicolumn{1}{|c|}{$\operatorname{Exp(B)}$} \\
\hline $\begin{array}{l}\text { Step } \\
\text { 1(a) }\end{array}$ & SAMVAVG & 0.001946 & 0.001626 & 1.432881 & 1 & 0.231295 & 1.001948 \\
\hline & SATMAVG & -0.01218 & 0.002318 & 27.594 & 1 & $1.5 \mathrm{E}-07$ & 0.987895 \\
\hline & GENDER2 & 0.020503 & 0.239248 & 0.007344 & 1 & 0.931706 & 1.020715 \\
\hline & AFRICANA & 0.018243 & 0.250917 & 0.005286 & 1 & 0.942041 & 1.01841 \\
\hline & HISPANIC & -0.16752 & 0.297037 & 0.318055 & 1 & 0.572779 & 0.845761 \\
\hline & OTHERETH & -0.3043 & 0.51735 & 0.345973 & 1 & 0.556402 & 0.737638 \\
\hline & CM1000 & -0.10233 & 0.043295 & 5.586662 & 1 & 0.018098 & 0.902729 \\
\hline & RAB500 & -0.06329 & 0.031176 & 4.121419 & 1 & 0.042344 & 0.938669 \\
\hline & BLUE & 0.962781 & 0.198456 & 23.53578 & 1 & $1.23 \mathrm{E}-06$ & 2.61897 \\
\hline & Constant & 10.26172 & 2.787848 & 13.54885 & 1 & 0.000232 & 28616.03 \\
\hline
\end{tabular}

a. Variable(s) entered on step 1: SAMVAVG, SATMAVG, GENDER2, AFRICANA, HISPANIC, OTHERETH, CM1000, RAB500, BLUE.

\section{Attrition Model (Nominal Regression)}

Case Processing Summary
\begin{tabular}{|l|l|r|l|}
\hline \multicolumn{1}{|l|}{} & N & $\begin{array}{l}\text { Marginal } \\
\text { Percentage }\end{array}$ \\
\hline $\begin{array}{l}\text { LVREASON Reason For } \\
\text { Leaving }\end{array}$ & $\begin{array}{l}1 \\
\text { Voluntary }\end{array}$ & 40 & 6.980803 \\
\hline & $\begin{array}{l}\text { 3 } \\
\text { Academic }\end{array}$ & 39 & 6.806283 \\
\hline
\end{tabular}




\begin{tabular}{|l|r|r|r|} 
& 9 & 494 & 86.21291 \\
\hline Valid & & 573 & 100 \\
\hline Missing & & 317 & \\
\hline Total & & 890 & \\
\hline Subpopulation & & 573 & \\
\hline
\end{tabular}

a. The dependent variable has only one value observed in 573 (100.0\%) subpopulations.

Model Fitting Information

\begin{tabular}{|c|c|c|c|c|}
\hline Model & $\begin{array}{l}\text {-2 Log } \\
\text { Likelihood }\end{array}$ & $\begin{array}{l}\text { Chi- } \\
\text { Square }\end{array}$ & $\mathrm{df}$ & Sig. \\
\hline $\begin{array}{l}\text { Intercept } \\
\text { Only }\end{array}$ & 569.1418 & & & \\
\hline Final & 472.4175 & 96.72429 & 24 & $\begin{array}{r}1.08 \mathrm{E}- \\
10\end{array}$ \\
\hline
\end{tabular}

Pseudo R-Square

\begin{tabular}{|l|r|}
\hline $\begin{array}{l}\text { Cox and } \\
\text { Snell }\end{array}$ & 0.155325 \\
\hline Nagelkerke & 0.24669 \\
\hline McFadden & 0.169948 \\
\hline
\end{tabular}

Likelihood Ratio Tests

\begin{tabular}{|l|c|c|c|c|}
\hline \multicolumn{1}{|c|}{ Effect } & $\begin{array}{c}\text {-2 Log } \\
\text { Likelihood } \\
\text { of } \\
\text { Reduced } \\
\text { Model }\end{array}$ & $\begin{array}{c}\text { Chi- } \\
\text { Square }\end{array}$ & \multicolumn{1}{c|}{ df } & Sig. \\
\hline Intercept & 473.6615 & 1.244047 & 2 & 0.536857 \\
\hline SAMVAVG & 473.0688 & 0.651279 & 2 & 0.722065 \\
\hline
\end{tabular}




\begin{tabular}{|l|r|r|r|r|} 
SATMAVG & 474.3428 & 1.925285 & 2 & 0.381882 \\
\hline AVG6WK & 506.7963 & 34.37878 & 2 & $3.43 E-08$ \\
\hline AVGDIF & 489.6457 & 17.22824 & 2 & 0.000182 \\
\hline MSGONE & 474.1538 & 1.736295 & 2 & 0.419728 \\
\hline MSGTWOMO & 484.2089 & 11.79139 & 2 & 0.002751 \\
\hline VARPLEBE & 474.1608 & 1.743299 & 2 & 0.418261 \\
\hline GENDER2 & 485.0717 & 12.65425 & 2 & 0.001787 \\
\hline AFRICANA & 475.0044 & 2.586934 & 2 & 0.274318 \\
\hline HISPANIC & 479.1759 & 6.758406 & 2 & 0.034075 \\
\hline OTHERETH & 473.9261 & 1.508636 & 2 & 0.470331 \\
\hline PIP & 480.6139 & 8.196452 & 2 & 0.016602 \\
\hline
\end{tabular}

The chi-square statistic is the difference in -2 log-likelihoods between the final model and a reduced model. The reduced model is formed by omitting an effect from the final model. The null hypothesis is that all parameters of that effect are 0 .

Parameter Estimates

\begin{tabular}{|l|l|r|l|l|r|l|}
\hline $\begin{array}{l}\text { LVREASON } \\
\text { Reason For } \\
\text { Leaving(a) }\end{array}$ & & B & $\begin{array}{l}\text { Std. } \\
\text { Error }\end{array}$ & Wald & df & Sig. \\
\hline & & & & & & \\
\hline 1 Voluntary & Intercept & -1.7645 & 2.302767 & 0.58714 & 1 & 0.443527 \\
\hline & SAMVAVG & 0.002178 & 0.002912 & 0.559502 & 1 & 0.454461 \\
\hline & SATMAVG & -0.00019 & 0.003555 & 0.002734 & 1 & 0.958299 \\
\hline & AVG6WK & -0.7936 & 0.269814 & 8.651066 & 1 & 0.003269 \\
\hline & AVGDIF & -0.873 & 0.367737 & 5.635775 & 1 & 0.017598 \\
\hline & MSGONE & 0.157253 & 0.400558 & 0.154123 & 1 & 0.694626 \\
\hline & MSGTWOMO & -0.94285 & 0.48405 & 3.794062 & 1 & 0.051435 \\
\hline & VARPLEBE & -0.27884 & 0.364368 & 0.585648 & 1 & 0.444107 \\
\hline & GENDER2 & 1.328021 & 0.375025 & 12.53974 & 1 & 0.000398 \\
\hline & AFRICANA & -0.92282 & 0.65482 & 1.986038 & 1 & 0.158756 \\
\hline & HISPANIC & 0.219087 & 0.484473 & 0.204501 & 1 & 0.651112 \\
\hline & OTHERETH & -1.05482 & 1.064814 & 0.981319 & 1 & 0.321873 \\
\hline & PIP & -1.52639 & 0.667079 & 5.235721 & 1 & 0.022128 \\
\hline & Intercept & -2.2495 & 2.573061 & 0.764313 & 1 & 0.381982 \\
\hline & SAMVAVG & -0.00072 & 0.003103 & 0.053637 & 1 & 0.816851 \\
\hline & SATMAVG & 0.005322 & 0.00386 & 1.900367 & 1 & 0.168037 \\
\hline 3 Academic & AVG6WK & -1.46206 & 0.293407 & 24.83074 & 1 & $6.26 \mathrm{E}-07$ \\
\hline & AVGDIF & -1.33713 & 0.367038 & 13.27159 & 1 & 0.000269 \\
\hline & MSGONE & -0.50981 & 0.433121 & 1.385455 & 1 & 0.239174 \\
\hline & MSGTWOMO & -1.41983 & 0.532543 & 7.108316 & 1 & 0.007673 \\
\hline & VARPLEBE & -0.45018 & 0.391463 & 1.32247 & 1 & 0.250149 \\
\hline & GENDER2 & -0.27811 & 0.538903 & 0.266323 & 1 & 0.605809 \\
\hline & & & & & & \\
\hline & & & & &
\end{tabular}




\begin{tabular}{|l|l|r|r|r|r|r|} 
& AFRICANA & 0.189558 & 0.539849 & 0.123294 & 1 & 0.72549 \\
\hline & HISPANIC & 1.25399 & 0.468738 & 7.156952 & 1 & 0.007467 \\
\hline & OTHERETH & 0.314344 & 0.809433 & 0.150817 & 1 & 0.697756 \\
\hline & PIP & 0.371306 & 0.445189 & 0.695625 & 1 & 0.404258 \\
\hline
\end{tabular}

a. The reference category is 9 .

\section{Performance Model (Ordinary Least Squares Model)}

Variables Entered/Removed (b)

\begin{tabular}{|r|l|l|l|}
\hline Model & Variables Entered & $\begin{array}{c}\text { Variables } \\
\text { Removed }\end{array}$ & Method \\
\hline & $\begin{aligned} \text { PIP, MSGTWOMO, GENDER2, OTHERETH, } \\
\text { HISPANIC, SAMVAVG, VARPLEBE, AFRICANA }\end{aligned}$ & \\
$\begin{array}{l}\text { African American, MSGONE, AVG6WK, } \\
\text { SATMAVG(a) }\end{array}$ &. & Enter \\
\hline
\end{tabular}

a. All requested variables entered.

b. Dependent Variable: AVGDIF

Model Summary

\begin{tabular}{|r|c|c|c|c|c|}
\hline Model & $\mathbf{R}$ & $\begin{array}{c}\text { R } \\
\text { Square }\end{array}$ & $\begin{array}{c}\text { Adjusted } \\
\mathbf{R} \\
\text { Square }\end{array}$ & $\begin{array}{c}\text { Std. } \\
\text { Error of } \\
\text { the } \\
\text { Estimate }\end{array}$ & \\
\hline 1 & 0.420727 & 0.177012 & 0.160875 & 0.442779 & \\
\hline
\end{tabular}

a. Predictors: (Constant), PIP, MSGTWOMO, GENDER2, OTHERETH, HISPANIC, SAMVAVG, VARPLEBE, AFRICANA African American, MSGONE, AVG6WK, SATMAVG

Coefficients (a)

\begin{tabular}{|c|c|c|c|c|c|c|}
\hline Model & & $\begin{array}{l}\text { Unstandardized } \\
\text { Coefficients }\end{array}$ & & $\begin{array}{c}\text { Standardized } \\
\text { Coefficients }\end{array}$ & $\mathbf{t}$ & Sig. \\
\hline & & $\mathrm{B}$ & $\begin{array}{l}\text { Std. } \\
\text { Error }\end{array}$ & Beta & & \\
\hline 1 & (Constant) & -0.0211 & 0.25119 & & -0.084 & 0.933086 \\
\hline
\end{tabular}




\begin{tabular}{|l|l|r|r|r|r|r|}
\hline & AVG6WK & -0.24178 & 0.026952 & -0.39135 & -8.97086 & $4.39 E-18$ \\
\hline & SAMVAVG & -0.00026 & 0.000316 & -0.03462 & -0.82653 & 0.408856 \\
\hline & SATMAVG & 0.001111 & 0.00037 & 0.132176 & 2.9982 & 0.002836 \\
\hline & MSGTWOMO & 0.111319 & 0.044708 & 0.105647 & 2.489935 & 0.013065 \\
\hline & MSGONE & 0.007018 & 0.047434 & 0.006259 & 0.147953 & 0.882433 \\
\hline & VARPLEBE & 0.003163 & 0.039431 & 0.00325 & 0.080206 & 0.936102 \\
\hline & GENDER2 & -0.06133 & 0.051536 & -0.04641 & -1.18996 & 0.234564 \\
\hline & AFRICANA & & & & & \\
& African American & -0.08943 & 0.055392 & -0.06738 & -1.61441 & 0.107001 \\
\hline & HISPANIC & -0.16049 & 0.057912 & -0.11271 & -2.77125 & 0.005769 \\
\hline & OTHERETH & -0.16054 & 0.085687 & -0.07287 & -1.87362 & 0.061503 \\
\hline & PIP & -0.06984 & 0.051578 & -0.05696 & -1.35411 & 0.176247 \\
\hline
\end{tabular}

a. Dependent Variable: AVGDIF 


\section{LIST OF REFERENCES}

Academic Dean Instruction 1531.56J. (2004) United States Naval Academy. Plebe Advising Handbook.

Annual Report of the Academic Center (2002-2003), United States Naval Academy.

Astin, A. (1993). What matters in college? San Francisco: Jossey-Bass.

Bettinger, E. \& Long, B.T. (2004). Shape up or ship out: The effects of remediation on students at four-year colleges. National Bureau of Economic Research. Cambridge, Ma.

Blanc, R.A., Debuhr, L.E., \& Martin, D.C. "Breaking the attrition cycle: The effects of supplemental instruction on undergraduate performance and attrition." Journal of Higher Education, 54 (1983) 80-90.

Bohlan, H.R., Bonham, B.S., Claxton, C., \& Bliss, L.B. (1992, November). The state of the art in developmental education. Paper presented at the National Conference on Research in Developmental Education, Charlotte, NC.

Boylan, H. R., (1999). Exploring Alternatives to Remediation, Journal of Developmental Education, 22 (3).

Boylan, H.R., Bliss, L.B., \& Bonham, B.S. (1997). Program components and their relationship to student performance. Journal of Developmental Education, 20(3), 2-8.

Brewin, C.R., Furnham, A., \& Howes, M. "Demographic and psychological determinants of homesickness and confiding among students.” British Journal of Psychology, 80, pg. 467-477.

Center for Supplemental Instruction, University of Missouri-Kansas City Center for Academic Development. Review of research concerning the effectiveness of SI from The University of Missouri and other institutions from across the United States. 1997.

Congos, D.H. \& Schoeps, N. “A model for evaluating retention programs.” Journal of Developmental Education, 21 (2) 1997.

Congos, D.H. \& Schoeps, N. "Does supplemental instruction really work and what is it anyway?” Studies in Higher Education, 18 (2), 1993.

Debmo, M.H., \& Seli, H.P.. Students’ resistence to change in learning strategies courses. Journal of Developmental Education, 27(3), 2-11. 
Doughtery, T.K. \& Lane, E.J. A longitudinal study of academic and social predictors of college attrition. Social Behavior and Personality, 1999.

Fidler, P.P. \& Godwin, M.A. (1994). Retaining african-american students through the freshman seminar. Journal of Developmental Education, 17(3), 34-40.

Friedlander, J. (1980). Are college support programs and services reaching high-risk students? Journal of College Student Personnel, 21, 23-38.

Hodges, R., (2001). Encouraging high-risk student participation in tutoring and supplemental instruction, Journal of Developmental Education, 24 (3).

Karabenick, S.A., \& Knapp, J.P. (1988). Help seeking and the need for academic assistance. Journal of Educational Psychology, 80, 406-408.

Martin, D.C,, Blanc, R.A., Deburh, L.E., Alderman, H., Garland, M \& Lewis, C. (1993) Supplemental instruction: a model for student academic support, (Kansas City, Mo, University of Missouri Student Learning Center of the University of Missouri-Kansas City and ACT National Center for the Advancement of Educational Practices).

Martin, D.C. \& Arendale, D. (1993). Supplemental Instruction in the first college year. In D.C. Martin, \& D Arendale (Eds.), Supplemental Instruction: Improving firstyear student success in high-risk courses. $2^{\text {nd }}$ ed., (pp. 11-18). Columbia, SC: National Resource Center for The Freshman Year Experience and Students in Transition) (ERIC Document Reproduction Service, No. ED 354 839).

Maxwell, M. (1992). Cost effective alternatives to tutoring. Journal of Learning Improvement, 1(1), 1-4.

Maxwell, M. (1985). Improving student learning skills ( $2^{\text {nd }}$ ed.). San Francisco: Jossey Bass.

McCarthy, A. \& Smuts, B. (1997) Assessing the effectiveness of supplemental instruction: A critique and a case study. Studies in Higher Education, 22(2), 221232.

Midshipmen Groups Study Program (n.d.) Retrieved Jan 13, 2005 from World Wide Web: http://usna.edu/MGSP/become_a_leader.htm

Morrison, B.H. (1999). Acknowledging student attributes associated with academic motivation, Journal of Developmental Education, 23(2).

National Center Education Statistics (n.d.) Retrieved Apr 18, 2005 from World Wide Web: http://nces.ed.gov/surveys/bps/\#findings 
National Association for Developmental Education (2005, Feb 23) Retrieved Feb 23, 2005 from the World Wide Web: http://www.nade.net/index.htm

Noel, L, Levitz R., Saluri, D., \& Associates. (1985). Increasing students retention: effective programs and practices for reducing the dropout rate. San Francisco: Jossey-Bass, Inc.

Patrick, John, Furlow, John W., \& Donovan, Sharon, "Using a comprehensive academic intervention program in the retention of high-risk students," 1988(1): 29-34.

Simpson, M.L, Hynd, C.R., Nist, S.L., \& Burrell, K.I. (1997). College academic assistance programs and practices. Educational Psychology Review. 9(1), 39-87.

Tinto V. (1997). Leaving college: rethinking the causes and cures of student attrition. Chicago: The University of Chicago Press.

Turnbull, W.W. (1986). Involvement: The key to retention. Journal of Developmental Education, 10(2), 6-11.

United States Naval Academy Academic Center (2005, Feb 12) Retrieved Feb 12, 2005 from the World Wide Web: http://www.usna.edu/AcCenter/.

United States Naval Academy Academic Dean and Provost Intsruction 1531.34A: Academic Support Programs. 25 Aug 92.

Wambach, C. \& Brothen, T. Toward a developmental theory for developmental educators. Journal of Developmental Education, 24(1).

Watson, A.W. (2001). Identifying midshipman for academic assistance using entry variables. Naval Postgraduate School, Monterey, Ca. 
THIS PAGE INTENTIONALLY LEFT BLANK 


\section{INITIAL DISTRIBUTION LIST}

1. Defense Technical Information Center

Ft. Belvoir, Virginia

2. Dudley Knox Library

Naval Postgraduate School

Monterey, California

3. Nimitz Library

United States Naval Academy

Annapolis, Maryland

4. Professor William R. Bowman

United States Naval Academy

Department of Economics

Annapolis, Maryland

5. Professor Alice M. Crawford

Naval Postgraduate School

Graduate School of Business and Public Policy

Monterey, California

6. Commander Christopher X. Kennedy

Director, LEAD Program

United States Naval Academy

Annapolis, Maryland

7. Major David M. Fallon

Millersville, Maryland 